AVALIAÇÃO DA QUALIDADE DE ALGUMAS VARIEDADES

DE MORANGO PARA O PROCESSO DE CONGELAÇÃO

SHIRLEY APARECIDA GARCIA BERBARI

\begin{abstract}
Dissertação apresentada à Escola Superior de Agricultura "Luiz de Queiroz", da Universidade de são Paulo, para obtenção do título de Mestre em Ciências, área de concen tração - Ciência e Tecnologia de Alimentos.
\end{abstract}

\footnotetext{
$P$ I R A C I C A B A

Estado de São Paulo - Brasil

Agosto - 1992
} 


\title{
AVALIAÇÃO DA QUALIDADE DE ALGUMAS VARIEDADES \\ DE MORANGO PARA O PROCESSO DE CONGELAÇÃO
}

\author{
SHIRLEY APARECIDA GARCIA BERBARI \\ Engenheira de Alimentos
}

Orientador: Prof. Dr. JO§O NUNES NOGUEIRA

Dissertação apresentada à Escola Superior de Agricultura "Luiz de Queiroz", da Universidade de São Paulo, para obtenção do título de Mestre em Ciênciäs, área de concen tração - Ciência e Tecnologia de Alimentos.

P I R A C I C A B A

Estado de São Paulo - Brasil

$$
\text { agosto - } 1992
$$


Fichá catalografica preparada pela Seçao de Livros da Divisão de Biblioteca e Documentação - PCAP/USP

Berbari, Shirley Aparecida Garcia

B484a Avaliação da qualidade de algumas variedades de morango para o processo de congelacão. Piracicaba, 1992 .

90p. ilus.

Diss. (Mestre) - ESALQ

Bibliografia.

1. Morango - Variedade - Conge lamento 2. MorangoTecnologia I. Escola Superior de Agricultura Luiz de Queiroz, Piracicaba

CDD 664.80475 


\section{AVALIAÇÃO DA QUALIDADE DE ALGUMAS VARIEDADES \\ DE MORANGO PARA O PROCESSO DE CONGELAÇÃO}

SHIRLEY APARECIDA GARCIA BERBARI

Aprovada em: 03.09.1992

Comissão Julgadora:

Prof. Dr. João Nunes Nogueira ESALQ/USP

Prof. Dr. Homero Fonseca ESALQ/USP

Prof. Dr. Keigo Minami ESALQ/USP

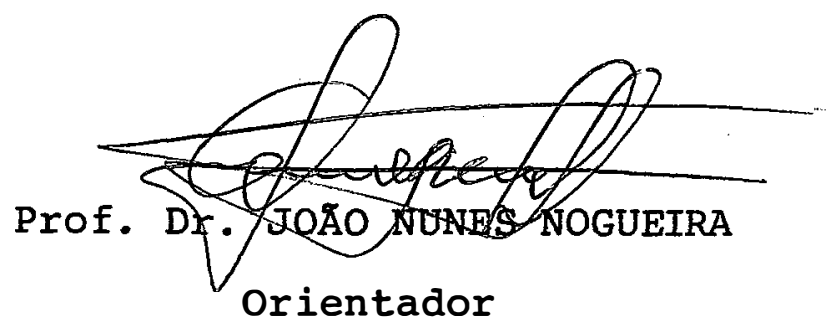


Com carinho, Ao meu pai Heros (in memorian) A minha mãe Shirley e a minha irmã Paula, dedico este trabalho. 


\section{SOMARTO}

Página

LISTA DE FIGURAS ......................... i

LISTA DE TABELAS ........................... ii

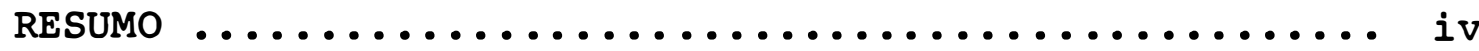

SUMMARY $\ldots \ldots \ldots \ldots \ldots \ldots \ldots \ldots \ldots \ldots \ldots \ldots \ldots \ldots \ldots \ldots \ldots \ldots$

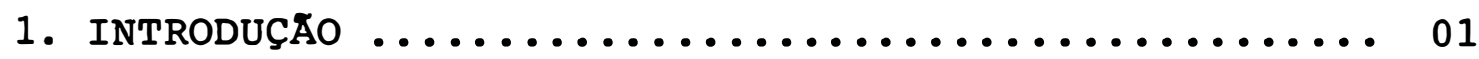

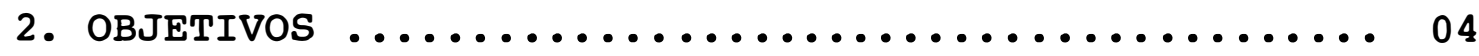

3. REVISÃo de LITERATURA $\ldots \ldots \ldots \ldots \ldots \ldots \ldots \ldots \ldots \ldots$

3.1. Variedades de morango .................. 06

3.2: o congelamento .................... 08

3.3. Tratamentos de pré-congelamento ........... 10

3.4. Armazenamento congelado .............. 18

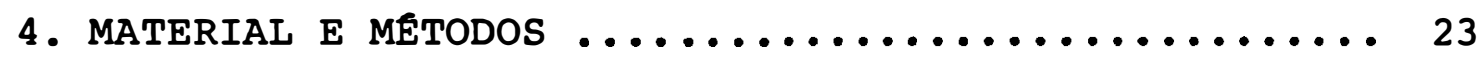

4.1. Matéria-prima .................... 23

4.2. Caracterização da matéria-prima $\ldots \ldots \ldots \ldots \ldots .24$

4.2.1. Análises físicas ............... 24

4.2.2. Análises químicas $\ldots \ldots \ldots \ldots \ldots \ldots \ldots . \ldots \ldots$

4.2.3. Análises sensoriais ............. 30

4.3. Processamento ........................ 33

4.3.1. Tratamentos de pré-congelamento ...... 34

4.3.2. Acondicionamento ................ 36

4.3.3. Congelamento e armazenamento congelado. 36

4.4. Avaliação do produto final .............. 36 
Pågina

4.4.1. Análises físicas ............... 37

4.4.2. Análises químicas .............. 40

4.4.3. Análises sensoriais ............. 40

5. RESULTADOS E DISCUSSAO $\ldots \ldots \ldots \ldots \ldots \ldots \ldots \ldots \ldots \ldots . \ldots \ldots$

5.1. Caracterização da matéria-prima .......... 42

5.1.1. Análises físicas ............... 42

5.1.2. Análises químicas ............... 44

5.1.3. Análises sensoriais ............ 47

5.2. Avaliação do produto final .............. 49

5.2.1. Análises físicas ............... 49

5.2.2. Análises químicas .............. 60

5.2.3. Análises sensoriais ............. 73

6. CONCLUSOES .......................... 80

7. REFERENCIAS BIBLIOGRAFICAS $\ldots \ldots \ldots \ldots \ldots \ldots \ldots \ldots . \ldots 3$ 
TABELA 11 - Sólidos solúveis (Brix) dos morangos con67 gelados - parte sólida (frutos) ........

TABELA 12 - Sólidos solúveis (Brix) dos morangos congelados - parte líquida (líquido exsudado)

TABELA 13 - Vitamina C (mg/100g amostra) dos morangos congelados - parte sólida (frutos) ......

TABELA 14 - Vitamina C (mg/100 g líquido) dos morangos congelados - parte líquida (líquido exsudado) $\ldots . \ldots \ldots \ldots \ldots \ldots \ldots \ldots \ldots$

TABELA 15 - Avaliação sensorial dos morangos congelados - variedade IAC-Princesa Isabel .... 76

TABELA 16 - Avaliação sensorial dos morangos congelados - variedade sequóia ..............

TABELA 17 - Avaliação sensorial dos morangos congelados - variedade Reiko ................

TABELA 18 - Avaliação sensorial dos morangos congelados - variedade Chandler ............. 


\section{AVALIAÇÃo DA QUALIDADE DE ALGUMAS VARIEDADES \\ DE MORANGO PARA O PROCESSO DE CONGELAÇÃo}

Candidato : Shirley Aparecida Garcia Berbari

Orientador: Prof. Dr. João Nunes Nogueira

\section{RESUMO}

o presente trabalho de pesquisa visou avaliar no processo de congelamento, o comportamento de quatro novas variedades de morango: Sequóia, IAC-Princesa Isabel, Reiko e Chandlér.

A matéria-prima e o produto final foram avaliados quanto às características físicas, quimicas e sensoriais. Foram realizadas medidas objetivas de textura, cor, suculência, teor de sólidos solúveis, teor de vitamina $\mathrm{C}, \mathrm{pH}$, acidez total titulável, perda de suco por exsudação e atividade da polifenoloxidase e peroxidase. Subjetivamente foram avaliados o sabor, a textura e a cor.

o preparo dos frutos para o congelamento compreendeu os procedimentos normais de limpeza, corte em metades e os tratamentos de pré-congelamento, que utilizaram: sa carose, cálcio $\left(\mathrm{CaCl}_{2}\right)$, pectina e aplicação de calor. Os prô dutos foram acondicionados em latas com capacidade para 450g, 
revestidas internamente com vernis epóxi, recravadas e em se guida congelados a $-25^{\circ} \mathrm{C}$. O comportamento dos produtos processados foi avaliado aos 45, 90, 135 e 180 dias de armazena mento congelado.

Os resultados mostraram que a variedade Chandler foi a mais adequada para o congelamento, seguida pelas variedades Reiko, Sequóia e IAC-Princesa Isabel. A variedade Chandler foi superior às demais em todos os atributos de qua lidade, incluindo textura, cor e sabor. 0 armazenamento congelado não afetou as características químicas dos morangos e os tratamentos de pré-congelamento tiveram efeito positivo principalmente sobre a textura e sobre a quantidade do liqui do exsudado durante o descongelamento dos produtos. 


\section{QUALITY EVALUATION OF SOME STRAWBERRY \\ VARIETIES FOR FREEZING}

Author : Shirley Aparecida Garcia Berbari

Adviser: Prof. Dr. João Nunes Nogueira

\section{SUMMARY}

The present research work was carried out to evaluate four new strawberry varieties for freezing: Sequóia, IAC-Princesa Isabel, Reiko e Chandler.

The raw material and the final product were evaluated by physical, chemical and sensorial analysis. Texture, succulency, soluble solids, ascorbic acid, $\mathrm{pH}$, titratable acidity, dripping losses, poliphenoloxidase and peroxidase activities were determined by objective methods. Flavor texture and color were also evaluated by sensorial methods.

The raw material for processing was prepared through normal proceedings such as cleaning in running water, cut in halves and pre-freezing treatments by using sucrose, calcium chloride $\left(\mathrm{CaCl}_{2}\right)$, pectin and heat treatment. The packaging of fruits was accomplished in $450 \mathrm{~g}$ enameled cans (epoxi sanitary enamel on body and tops), sealed and frozen 
at $-25^{\circ} \mathrm{C}$. The quality of the final product was evaluated at $45,90,135$ and 180 days of frozen storage.

The results showed that variety Chandler was more adequate for freezing, followed by varieties Reiko, Sequóia and IAC-Princesa Isabel. Chandler was superior in terms of texture, color and flavor. The frozen storage did not affect the strawberries chemical characteristics and pre-freezing treatments had positive effects mainly on texture and dripping losses during the products thawing. 


\section{AGRADECIMENTOS}

- Ao corpo docente e aos funcionários do Departamento de Ciência e Tecnologia Agroindustrial da Escola Superior de Agricultura "Luiz de Queiroz" - USP, por permitir e apoiar a realização deste trabalho.

- Ao Prof. Dr. João Nunes Nogueira, pela orientação e colaboração na elaboração deste trabalho.

- Aos Srs. Tatuo Sasiki e Oswaldo Sasiki, pela doação da ma téria-prima necessária à realização deste trabalho.

- Ao Pesquisador Científico Francisco Antônio Passos, pelo auxílio na obtenção da matéria-prima necessária a este trabalho.

- As Engenheiras de Alimentos Paula Elaine Garcia Berbari e Regina Kitagawa e à Sra. Shirley Garcia Berbari, pelo auxílio no transporte da matéria-prima do campo para o labo ratório.

- Aos técnicos Ivani Aparecida Marchetto Moreno e José Carlos Teixeira Mendes, pelo apoio na realização da parte prática deste trabalho.

- Ass Dras. Sonia Dedeca da Silva Campos e Vera Lúcia Pupo Ferreira, pelo apoio na realização da parte prática deste trabalho.

- Ao Conselho Nacional de Desenvolvimento Cientifico e Tecnológico - CNPq e à Fundação de Amparo à Pesquisa do Estado de São Paulo - FAPESP, pelo apoio financeiro a rea lização deste trabalho. 
- Engenheiranda Elisa Sayoko Nakagima pela realização dos gráficos referentes às análises de cor dor frutos.

- A equipe de analistas sensoriais que participaram da avaliação sensorial realizada no presente trabalho.

- Ao Dr. Zeno José de Martin pelo auxilio na elaboração do "Summary" deste trabalho.

- A equipe de bibliotecárias do Instituto de Tecnologia de Alimentos - ITAL, pela correção das citações bibliográficas deste trabalho.

- Ao Pesquisador Científico José Eduardo Paschoalino pelas sugestões dadas a este trabalho.

- A Sra. Sônia Maria Barsi Pereira pela datilografia deste trabalho.

- A todos que de alguma maneira contribuiram para a execução deste trabalho. 


\section{INTRODUÇÃO}

o morango Fragaria x ananassa Duch, é um fruto de clima temperado, com gosto e aroma agradáveis, textura suculenta, sendo por isso muito apreciado e valorizado.

o sabor morango, natural ou sintético, é o pre ferido, quando em comparação ao de muitas outras frutas, fazendo com que o fruto seja bastante consumido, tanto "in natura", como em uma grande variedade de produtos com ele formulados.

O Estado de São Paulo é o maior produtor e consumidor de morangos no País, abastecendo também o Rio de Janeiro (segundo mercado para esse produto) e mercados distantes como o de Belém e Recife. Em certas ocasiões, nos picos de safra, principalmente nos meses de junho a agosto, che ga a ser exportado para a Argentina.

De acordo com informações obtidas no Instituto de Economia Agrícola (IEA) e na Coordenadoria de Assistên cia Técnica Integral (CATI), a cultura do morangueiro atingiu na última década uma área cultivada de 600-800 hectares/ /ano e uma produção de 35 a $40 \mathrm{mil}$ toneladas/ano. No periodo de 1987-1989, a estimativa anual da área cultivada foi de 
670-810 hectares com produção de $26.000-34.000$ toneladas (LISBÃO, 1991). Desta produção anual, 908 consistiram das va riedades IAC 2712, Monte Alegre e Guarani, sendo os outros 108 restantes distribuidos entre diversas outras variedades, dentre as quais encontram-se a Sequóia, Chandler, Reiko lou Leiko) e IAC-Princesa Isabel.

Em conjunto com as excelentes caracteristicas organolépticas, o morango também apresenta uma alta perecibí lidade, podendo ser armazenado por pequenos periodos $\left(\begin{array}{lll}4 & \text { a }\end{array}\right.$ dias, no máximol, a uma temperatura entre 4 a $0^{\circ} \mathrm{C}$. Desta for ma, o congelamento apresenta-se como a alternativa mais adequada, pois entre os vários métodos de conservação de alimen tos, é o que proporciona menores danos aos frutos, tanto do ponto de vista nutricional, como organoléptica. Segundo NEVES FILHO (1986), o congelamento tem sido o método preferido na conservação de morango devido à sua demasiada fragilidade.

No Brasil, a comercialização do morango, a ní vel de consumo, se dá basicamente através de frutos "in natụ ra", sob refrigeração.

Não foram encontrados na literatura dados sobre a industrialização de morango, destinados ao mercado interno, quer por congelamento ou por apertização, restringindo-se, portanto, a oferta do fruto apenas ao seu periodo de safra. Fora deste, o preço do produto, quando encontrado, se torna proibitivo. 
As poucas indústrias que processam o fruto, para atender ao mercado na entressafra, o fazem na forma de polpa congelada, a fim de que esta seja utilizada como matéria-prima pelas indústrias na elaboração de bombons, iogurtes, sorvetes e geléias.

O desenvolvimento de uma tecnologia adequada, utilizando variedades selecionadas para o processo de congelação, permitirá às indústrias a oportunidade de oferecer um produto de boa qualidade, a um preço acessivel, podendo, assim, ser destinado tanto ao mercado interno como para a exportação, trazendo benefícios diretos para as indústrias, prọ dutores e consumidores. 


\section{OBJETIVOS}

Este trabalho foi desenvolvido visando avaliar a qualidade de algumas variedades de morango no processo de congelação, através de caracterizações física, química e organoléptica destas e do estudo da influência da utilização

de tratamentos de pré-congelamento, visando melhorar a quali dade do produto final.

As variedades de morango incluidas no presente estudo foram: "IAC-Princesa Isal", "Chandler", "Reiko" e "Sequóia" • 


\section{REVISÃO DE LITERATURA}

A matéria-prima é básica para a qualidade e caracteristica do produto congelado. A seleção de variedade, a região de cultivo, as práticas culturais e o estágio de ma turação na colheita, assim como o manuseio do produto colhido antes do processamento, são fatores importantes a serem considerados (PASCHOALINO et al., 1979).

A adequabilidade para congelamento de diversas variedades de morango, assim como a avaliação de fatores que afetam a qualidade deste fruto, quando conservado por con gelamento, buscando soluções favoráveis que reduzam ou elimi nem tais influências, têm sido objeto de estudos em todo mun do (PASCHOALINO, 1977).

Entre as diversas variedades da mesma espécie de fruta ou hortaliça, existem grandes diferenças de sabor, cor, tamanho, forma, odor, textura, armazenamento, resistência a danos no transporte, nutrientes, resistência a moléstias, espessura da casca, tamanho e número de sementes, rendimento por área, época de maturação e outras propriedades, que irão afetar a adequabilidade do fruto ou hortaliça para este ou aquele determinado método de conservação (PASCHOALI- 
No et al., 1979). Assim, uma variedade de morango pode ser ade quada para a elaboração de geléias e não, para o congelamento.

\subsection{Variedades de morango}

Dentre as variedades de morango existentes no Brasil, merecem destaque especial aquelas que vêm sendo sele cionadas ou adaptadas pelo Instituto Agronômico de Campinas (IAC) . São elas: IAC-Princesa Isabel, Reiko, Sequóia e Chandler.

A variedade IAC-Princesa Isabel (Fragaria xananassa Duch.)' foi selecionada do cruzamento realizado em 1981 entre os cultivares Alemanha e IAC Jundiai. Os testes iniciais de campo, que elegeram a planta no 10 desse cruzamento como promissora, foram realizados em Jundiaí. Desde 1987, as avaliações têm prosseguido em Monte Alagre do Sul e Piedade, nesta última em condições de cultivo comercial. o nome escolhido è uma homenagem à Princesa Isabel, pela comemoração do Centenário da Abolição da Escravatura no Brasil, em 1988 (IN $\underline{S}$ TITUTO AGRONOMICO DE CAMPINAS, 1989).

Com o objetivo de criar uma nova variedade de morango, duas linhagens de plantas foram selecionadas em 1969. Uma foi chamada FS-3, a qual possuía uma coloração vermelha e um excelente sabor. Os frutos desta linhagem foram derivados do cruzamento de uma variedade comercial denominada Fuku da, com uma outra variedade 'HS-1', que possui um crescimen- 
to vigoroso e um formato grande e que foi derivada de uma va riedade comercial denominada Harunoka. Em 1973 após o cruzamento de FS-3 e HS-1 com o hibrido "Fl", 1300 plantas foram melhoradas. A seguir, conduziu-se uma seleção em viveiro e finalmente um hibrido F1 (FS-3 $x$ HS-1)-11 foi selecionado. Este hibrido foi chamado de "Reiko" que, quando comparado com as variedades Hokowase e Harunoka, apresentou maior teor de açúcar, acidez, vitamina $C$ e melhor sabor (NARUKAMA et al., 1981).

A Sequóia é uma variedade americana, inicialmente testada em 1956, com o nome de Cal. 56.124-12, origina da do cruzamento entre 2 híbridos Ca. 52.16-15 e Cal. 5151-1 e finalmente selecionada pela "University of California South Coast Field Station", Santa Ana, em 1958. As plantas desta variedade se destacaram em crescimento, vigor, atratividade e quando comparada com as outras variedades da Universidade, foi considerada a melhor. Os frutos são particulanmente atraen tes por causa do tamanho grande, da aparência cônica alongada e película vermelha escura (BRINGHURST\& VOTH, 1968).

A variedade Chandler é largamente cultivada nos Estados Unidos da América, para a produção de polpa congelada, utilizada na formulação de sorvetes, iogurtes, confeitos e outras sobremesas. No entanto, até o presente momen to não foi encontrado material bibliográfico referente ao de senvolvimento desta variedade. 
SISTRUNK \& MOORE (1967) estudaram 20 variedades americanas de morango. As diversas amostras foram submetidas a análises objetivas e subjetivas e os resultados mostraram que os valores do ponto de maturação e do tamanho dos frutos colhidos no mesmo periodo, foram fatores que influenciaram nas caracteristicas de qualidade dos morangos congela dos.

\section{2. o congelamento}

Ao se retirar calor da água no estado líquido, ou em outras palavras, reduzir sua temperatura, haverá menor atividade de suas moléculas. A água passa do estado lí quido para o sólido ou vice-versa a uma temperatura que se convencionou como $0^{\circ} \mathrm{C}$ (sob pressão atmosférica). Como resultado desta redução de temperatura e de atrações mútuas, as moléculas tendem a se agregar em cristais. Este fenômeno recebe o nome de cristalização e nele se baseia o princípio da conservação de alimentos através do abaixamento de temperatu彑 ra destes, ou seja, por congelamento (NEVES FILHO, 1986).

No caso de sistemas biológicos ou de alimentos, a cristalização da água presente nestes, é extremamente complexa em função de um grande número de variáveis, pois a temperatura, em que a água contida nos vegetais começa a con gelar, depende do seu teor de substâncias solúveis.

As frutas e hortaliças utilizadas no congelamento contèm de forma geral 75 a 958 de água, 4 a $23 \%$ de só- 
lidos solúveis e de 0,5 a 88 de insolúveis. Devido à larga faixa de sólidos solúveis, o congelamento destes produtos tem início a temperaturas que variam de $-0,5^{\circ} \mathrm{C}$ até $3,5^{\circ} \mathrm{C}$. Para os morangos que têm aproximadamente $9 \%$ de sólidos solúveis, o congelamento tém início ao redor de $-1,0^{\circ} \mathrm{C}$ (WHITEMAN, citado por NEVES FILHO, 1986).

A velocidade de congelamento, ou seja, o tempo gasto para que o conteúdo de água dos alimentos passe do estado líquido para o sólido, irá influenciar a manutenção da qualidade do produto "in natura", afetando atributos como sabor, aroma, cor e textura. Assim, quanto mais rápido for ultrapassada a zona de cristalização da água, de 0 a $-4{ }^{\circ} \mathrm{C}$, melhor será a qualidade do produto (PASCHOALINO, 1989).

Segundo DELGADO et al. (1990), os valores das temperaturas caracteristicas de congelamento mudam com o cul tivar, devido às diferenças que estas apresentam em seus con teúdos de água, ou seja, as temperaturas características de congelamento são mais baixas para as variedades que contêm maior teor de sólidos. Assim, as variedades Flórida e Tioga, com teores de sólidos solúveis em torno de $5 \%(\mathrm{~m} / \mathrm{m})$ e conteú do de água de $898(p / p)$ e $878(p / p)$, apresentam temperaturas caracteristicas de congelamento de $-2,8^{\circ} \mathrm{C}$ e $-4,0^{\circ} \mathrm{C}$, respecti vamente.

Desta forma, o congelamento dos morangos não se dará no patamar de $0^{\circ} \mathrm{C}$, como na água pura. Como visto anteriormente, haverá uma faixa de temperatura que deverá ser 
ultrapassada rapidamente, de acordo com recomendações do "International Institute of Refrigeration" (GUTSCHMIDT, J. citado por NEVES FILHO, 1986).

Quando a zona de cristalização da água não é ultrapassada rapidamente, haverá uma influência danosa sobre a qualidade do morango congelado. Existem várias teorias que tentam explicar este fato, como a teoria da perfuração da cé lula, que é a hipótese mais amplamente divulgada e persisten te. De acordo com esta teoria, as paredes celulares são perfuradas pelos cristais de gelo em crescimento. No descongela mento, os conteúdos celulares fluem por essas diminutas perfurações. Quando isso ocorre, há um retalhamento interno do fruto e a intensidade do dano resultante é uma função do tamanho dos cristais e do tempo da congelação. Existem, ainda, as teorias do dano osmótico e da mudança coloidal (PASCHOALI NO, 1989) .

\subsection{Tratamentos de pré-congelamento}

Ao serem descongelados, os morangos precisam apresentar características como sabor e acidez pronunciados e agradáveis, cor vermelho - brilhante (mesmo após longo tem po de armazenamento), tamanho bom e uniforme e, principalmen te, textura firme (PASCHOALINO et al., 1973/1974).

Na avaliação da qualidade de morangos congela dos, as características sensoriais e texturais são os critérios freqüentemente utilizados (GUEGOV et al., 1982). 
A textura dos alimentos, notadamente a dos frutos, é um dos seus principais atributos de qualidade. As substâncias pécticas e os amidos são os componentes dos tecí dos vegetais, responsáveis pela textura dos frutos e hortalí ças. Os processamentos, aos quais estes alimentos são submetidos para sua conservação, influenciam profundamente a textura dos mesmos (SHERMAN, 1979).

Nos morangos congelados, a textura é considerada o mais importante indice de qualidade e também é o atrí buto que sofre maior degradação durante este tipo de processamento (SZCZENIAK \& SMITH, 1969). Assim, sua manutenção cons titui um desafio para os tecnologistas de alimentos.

A grande susceptibilidade dos morangos ao dano na textura não é surpreendente, quando se considera seu conteúdo extremamente baixo de sólidos, o que faz com que eles tenham uma estrutura polimérica muito intrincada, capaz de suportar uma grande quantidade de liquido (SZCzESNIAK \& SMITH, 1969).

Além da composição química, outros fatores co mo variedade, época de colheita e condições de cultivo podem afetar a textura dos frutos. A chuva e a umidade deixam os frutos menos firmes, pois estes absorvem muita água do solo, ficando com menor tempo de sólidos, assim como os frutos colhidos após o estádio ótimo de maturação são menos firmes (PASCHOALINO et al., 1973/74). 
BOURNE (1982) estudou o efeito da temperatura sobre a textura dos morangos e verificou que esta diminuiu. quando a temperatura foi aumentada. Por isso, os frutos que não são resfriados logo após a colheita resultam num produto congelado de melhor qualidade.

HUDSON et al. (1975a) estudaram a influência do meio de congelamento, a temperatura do xarope e o tempo em que os morangos permaneciam embebidos neste antes do congela mento, a temperatura e o tempo de armazenamento, e os valores de temperatura de congelamento e descongelamento sobre as características sensoriais dos frutos. A variedade estudada foi a Cambridge Favourite. Os resultados mostraram que a cor dos frutos pode ser melhorada se estes permanecerem submersos em xarope (60\%) por 3 horas antes de serem congelados e que a textura e o sabor tendem a melhorar quando a submersão é de 4 horas. Quando à temperatura não houve diferença signi ficativa para os frutos congelados e armazenados a $-18^{\circ} \mathrm{C}$ e $-32^{\circ} \mathrm{C}$. O tempo de armazenamento não afetou a aparência e a textura dos frutos, mas o sabor diminuiu com 0 passar dos dias.

Experimentos foram desenvolvidos para melhorar a qualidade do congelamiento doméstico de morango, variedade Cambridge Favourite, por adição de algumas substâncias, tais como: ácido ascórbico $(0,08 \%)$, lactato de cálcio (18), ácido ascórbico $(0,08 \%)$ + lactato de cálcio $(0,048)$, ácido cítrico $(0,048)$ e ácido tartárico $(0,048)$. Os frutos congela 
dos foram armazenados a $-18^{\circ} \mathrm{C}$ por aproximadamente 3 e 5 meses e foram utilizados testes de textura e análise sensorial para avaliar a qualidade do produto. Os aditivos utilizados apresentaram os seguintes resultados: as adições de ácido cí trico e ácido ascórbico + lactato de cálcio, para os dois pe riodos de armazenamento 3 e 6 meses melhoraram os sabor dos frutos. O ácido cítrico melhorou a cor e a aparência. A textura foi melhorada com a adição de lactato de cálcio + ácido ascórbico (HUDSON et al., 1975b).

HUDSON et al. (1977) também estudaram a influên cia de fatores como: adição de açúcar e de ácido ascórbico sobre a qualidade sensorial de morangos congelados domestica mente. Concluiram que o congelamento lento dos frutos, em xa rope $(60 \% \mathrm{~m} / \mathrm{m})$ resfriado, melhorou a qualidade dos frutos con gelados; o fatiamento dos frutos melhorou o sabor destes; 0 congelamento com açúcar refinado é mais conveniente e o congelamento rápido melhorou a cor e a aparência dos frutos; a adição de açúcar, após o congelamento, melhorou muito pouco a qualidade; e os frutos inteiros descongelados apresentaram melhor aparência do que os fatiados.

Com o objetivo de melhorar a firmeza dos frutos da variedade Cardinal, morangos muito maduros foram submetidos a tratamentos de pré-congelamento e de pré-processamento térmico (processamento de geléia). Os resultados mostraram que a imersão em soluções com 18 ou 28 de lactato de cálcio ou a infiltração a vácuo destas soluções fez com que 
os frutos se tornassem mais firmes, principalmente para os morangos em fatias, no caso da imersão e para os morangos in teiros, no caso da infiltração. Os frutos termicamente processados foram mais favorecidos do que os frutos congelados e descongelados (MAIN et al., 1986).

GARROTE \& BERTONE (1975) estudaram a impregna ção a vácuo com soluções de sacarose (10\%, 20\%, $30 \%$ e 50\%) em morangos cortados ao meio (variedade Tioga), a fim de verificar o efeito de diferentes valores de vácuo e respectivos tempos de aplicação, sobre os frutos congelados. Os melhores resultados foram obtidos com os seguintes tratamentos e tempos de aplicação de vácuo: tempo de impregnação: 2mini tempo de drenagem: $3 \mathrm{~min}$. O vácuo de $560 \mathrm{mmHg}$ foi o que conservou melhor aparência dos frutos e o que produziu uma maior penetração do xarope. A análise do efeito da velocidade de congelamento mostrou que o método rápido apresentou menores perdas de peso e de volume de suco exsudado, assim como melhor textura e maior pontuação na avaliação sensorial. o pré-tratamento de impregnação a vácuo de $560 \mathrm{mmHg}$ com solução de sacarose a 308, seguido do congelamento com Freon-12 líquido, demonstrou ser o mais conveniente.

A utilização de vácuo tem por objetivo evitar modificações de aroma, sabor e cor que podem ocorrer durante o congelamento e o armazenamento do morango, através de reações catalisadas por enzimas. Como os frutos não são normalmente branqueados, o emprego do vácuo não permitirá que caso 
existam enzimas nos morangos, estas utilizem $0 \mathrm{O}_{2}$ como substrato para provocarem mudanças indesejáveis no produto.

Com o mesmo objetivo de melhorar a qualidade do morango congelado, três variedades do fruto: Tioga, Tuff e Cambridge, foram submetidas a dois diferentes tratamentos de pré-congelamento: lmin de imersão em solução contendo 30 \& de açúcar $+0,38$ de amido $+0,38$ de ágar-ágar e lmin de imer são em solução com $0,288 \mathrm{CaCl}_{2}$ mais $0,58 \mathrm{NaCl}$. Os frutos foram analisados quanto à perda de líquido por exsudação, quali dade sensorial, sólidos solúveis $(\%), \mathrm{pH}$, acidez total titulável, atividade de peroxidase, firmeza, antocianinas totais e densidade óptica. Os resultados mostraram que o tratamento com sais $\left(\mathrm{CaCl}_{2}\right.$ e $\left.\mathrm{NaCl}\right)$ reduziu a perda de liquido por exsuda ção e que ambos os tratamentos produziram morangos com bom sabor e boa aparência e não afetaram a textura. A amostra-controle foi a preferida apenas do ponto de vista sensorial. O autor recomenda que os morangos sejam consumidos a tempera tura entre 0 e $5^{\circ} \mathrm{C}$, para evitar a perda de suco e preservar sua textura (FUSTER et al., 1985).

Para determinar a influência da remoção manual ou mecânica do cálice dos morangos sobre a perda de suco por exsudação, durante o descongelamento destes, sete variedades de morango foram estudadas por CRIVELLI \& ROSATI (1973). Os dados obtidos mostraram que o tipo de colheita não influenciou na percentagem de suco exsudado dos frutos, no desconge lamento. o efeito da imersão dos frutos, antes do congelamen 
to, em solução de ácido ascórbico, sais de cálcio e açúcar também foi avaliado. Apenas a adição de açúcar melhorou a qua lidade dos frutos congelados.

Os efeitos dos pré-tratamentos e do congelamento sobre diferentes variedades espanholas de morango também foram investigadas por FUSTER et al. (1984). Os tratamentos com adição de açúcar e sais foram aplicados e não tiveram grande influência sobre a textura do produto. Das variedades estudadas, a Cambridge foi considerada a melhor para congelamento.

Morangos, groselhas, ervilhas verdes e couves -flores foram imersos por 1-3 minutos em soluções contendo substâncias, como: metabissulfito de potássio e de aluminio, cloreto de cálcio, extrato de videira, casca de carvalho e chá verde, com o objetivo de reter o conteúdo de vitaminas destas frutas e hortaliças durante o congelamento e armazena mento congelado das mesmas. No caso dos morangos, a melhor retenção do conteúdo inicial de vitamina ocorreu nas amostras tratadas com solução de metabissulfito de potássio por lmin, com retenção de 87,08 do conteúdo inicial. Quando 0 mesmo tratamento foi aplicado por $3 \mathrm{~min}$, a retenção foi de $68,00 \%$ (KOROBKINA, 1978).

MORRIS et al. (1975) estudaram o comportamento de duas variedades de morango (Sunrise e Cardinal) quanto às influências que o cultivar, o armazenamento congelado, os tra tamentos de imersão em soluções contendo substâncias quími- 
cas e o tipo de embalagem podem ter sobre a qualidade dos mo rangos processados. Os frutos inteiros ou em fatias foram tra tados por imersão em soluções contendo: 18 ácido cítrico + $+0,58$ de lactato de cálcio; $200 \mathrm{mg}$ metabissulfito de potássio $+0,58$ de lactato de cálcio. Os resultados mostraram que a imersão em soluções contendo lactato de cálcio $(0,58)$ mais ácido citrico (1\%) ou apenas lactato de cálcio $(0,58)$, propi ciou a melhora da textura dos frutos em fatias.

A adição de fatias de morangos na proporção de $80 \%$ de verdes e $60 \%$ de maduros, colhidos mecanicamente, em purê de morangos maduros, foi estudada, para determinar o efeito da percentagem de frutas verdes na qualidade do purê. Os resultados mostraram que as frutas verdes e maduras, colhidas mecanicamente, quando adicionadas a purês aumentaram a viscosidade destes, mas diminuiu o teor de ácido ascórbico, de antocianinas totais, e em conseqüência acoloração ver melha também diminuida (SISTRUNk et al., 1983).

GUEGOV et al. (1982) estudaram a adequabilidade ao congelamento de 12 variedades de morango cultivadas na Bulgária. Foram realizadas análises físicas, químicas e sensoriais na matéria-prima e no produto final (fruto descongeladol. Foram consideradas como mais apropriadas para o conge lamento as variedades Belroubi, Cambridge Favourite e Sequóia, que apresentaram percentagem de perda de suco, por exsudação, muito inferiores as das outras variedades em estudo. Neste trabalho os frutos não foram submetidos a nenhum tratamento de pré-congelamento. 
A maioria dos tratamentos de pré-congelamento é realizada, a fim de que seja mantida a textura dos morangos "in natura", pois esta é a característica que mais sofre danos, quando os frutos são congelados, como já foi citado anteriormente.

\subsection{Armazenamento congelado}

Durante 0 armazenamento dos alimentos congela dos pode ocorrer um declínio na qualidade destes. A temperatura de $-18^{\circ} \mathrm{C}$ geralmente é empregada para o armazenamento da maioria dos alimentos congelados. As mudanças comumente encontradas são de ordem física ou química, visto que microrga nismos não se desenvolvem a temperaturas tão baixas (MICHENER, citado por TEIXEIRA NETO et al., 1979).

Dentre as mudanças físicas que ocorrem durante o armazenamento congelado das frutas e hortaliças, as mais importantes são a recristalização e a "queima" pelo frio. As oscilações de temperatura fazem com que a água contida nos alimentos congelados, em forma de gelo, se liquefaça e logo em seguida, com o abaixamento da temperatura, novamente se cristalize, ou seja, recristalize, mas desta vez de forma len ta e conseqüentemente com a formação de cristais de tamanho grande, que irão provocar diminuição da qualidade dos alimen tos. A "queima" pelo frio é causada pela sublimação da camada superficial de gelo do alimento provocando queima e desidratação do alimento congelado (BERNHARDT et al., 1979). 
Muitas transformações químicas podem ocorrer durante o armazenamento congelado dos alimentos. Para as fru tas e hortaliças, a perda de ácido ascórbico e a transformação da clorofila em feofitina são as mais importantes delas (BERNHARDT et al., 1979).

O conteúdo da vitamina $C$, na forma reduzida (ácido dehidroascórbico), foi estudado por DERBEDEVA \& KROTOV (1972), em morangos e groselhas, submetidas a diferentes con dições de congelamento e armazenamento congelado. Os métodos de congelamento utilizados foram: congelamento me meio líqui do, congelamento por "spray" de nitrogênio líquido ou congelamento rápido e as temperaturás de armazenamento foram de $-18^{\circ} \mathrm{C}$ e $-30^{\circ} \mathrm{C}$. O congelamento ocasionou, de maneira geral, uma perda de 168 no teor inicial de vitamina C dos frutos e - armazenamento à baixa temperatura $\left(-30^{\circ} \mathrm{C}\right)$ contribuiu para diminuição destas perdas.

Um outro estudo sobre a estabilidade do ácido ascórbico em frutos congelados foi realizado por KOROBKINA et al. (1975). Os frutos, sem branqueamento, foram congelados a $-30^{\circ} \mathrm{C}$, armazenados a $-18^{\circ} \mathrm{C}$ por 6-8 meses e descongelados à temperatura de 0 a $2{ }^{\circ} \mathrm{C}$ por 24 horas. Os morangos descongelados sofreram grandes perdas de vitamina $\mathrm{C}$ quando comparados com os frutos frescos, ficando com somente 13,18 do seu conteúdo original de vitamina.

WROLSTAD et al. (1970) estudaram o efeito do teor de antocianina, de ácido ascórbico, acidez total e pH 
sobre a qualidade da cor de morangos congelados. Foram utili zados cinco diferentes variedades de morangos cortados em fa tias e misturados com sacarose na proporção de 4:1. Os resul tados mostraram que $\circ \mathrm{pH}$ tem alta correlação com a qualidade da cor dos morangos congelados e que os frutos, que possuiam pH menor ou igual a 3,51, apresentavam cor aceitável após o descongelamerito. Ainda verificou que o conteúdo de antociani na que propicia uma cor aceitável dos frutos está entre 45,0 a $70,0 \mathrm{mg} / 100 \mathrm{~g}$.

Em estudo realizado por CHARLOMOWICZ et al. (1971), foram testadas quanto a mudanças nos pigmentos antocianínicos as seguintes variedades de morango: Senga Sengana, Zwyeiezca e Madame Moritot. De acordo com os resultados das análises cromatográficas, o pigmento antocianínico consiste de cianidina -3 - glicosideo e pelardolina -3 - glicosídeo. Durante o armazenamento congelado das variedades de morango ocorreram perdas de antocianina, sendo que após 3 me ses estas perdas foram de $10 \%, 17 \%$ e $31 \%$ de perda após 7 meses de armazenamento. As maiores perdas ocorreram para a variedade Madame Moritot.

Duas variedades de morango, Madame Moritot, Senga Sengana e uma variedade de framboesa, Bulgarian Ruby, foram congeladas por fluidização $\left(-30^{\circ} \mathrm{C}\right)$ e em câmara fria $\left(-28^{\circ} \mathrm{C}\right)$. A seguir as frutas foram armazenadas por mais de 20 meses $\mathrm{a}-18^{\circ} \mathrm{C}$ e $-20^{\circ} \mathrm{C}$. Foram realizadas avaliações da cor dos frutos, pelos sistemas HUNTER e CIE, imediatamente antes 
e após o congelamento, e em intervalos de cinco meses durante o armazenamento. Os resultados mostraram que o congelamen to causou uma queda na cor vermelha, que variou para a mesma variedade dependendo do método de congelamento. Todavia, du rante o armazenamento a estabilidade da cor vermelha mostrou uma tendência linear, independentemente do método de congela mento (SHAU, 1973a).

No mesmo experimento, SHAU (1973a), verificou que a variedade Madame Moritot "in natura" continha 15,71mg/ /100g de antocianina e Senga Sengana $34,21 \mathrm{mg} / 100 \mathrm{~g}$. Após o congelamento dos frutos, estes teores declinaram para 13,09$-14,1 \mathrm{mg} / 100 \mathrm{~g}$ e $28,25-30,24 \mathrm{mg} / 100 \mathrm{~g}$, respectivamente, dependen do do método de congelamento (câmara fria $-28^{\circ} \mathrm{C}$ e fluidização $\left.-30^{\circ} \mathrm{C}\right)$. Durante o armazenamento congelado, o teor de antocianina dos frutos diminuiu, independentemente das tempera turas utilizadas e passou para 7,04-7,54mg/100g para Madame Moritot e $21,37-23,36 \mathrm{mg} / 100 \mathrm{~g}$ para Senga Sengana, após 20 meses de armazenamento congelado.

A composição de açúcar livre durante o descon gelamento de morangos da variedade Senga Sengana foi estudada por SKREDE (1983). O teor de sacarose dos frutos desconge lados e drenados e do suco diminuiu em $70 \%$, enquanto os teores de frutose e glicose aumentaram, durante o descongelamen to a $-4^{\circ} \mathrm{C}$. O teor total de açúcar livre permaneceu constante e a degradação da sacarose pela atividade da invertase nos morangos ficou bem evidenciada no experimento. A inversão da 
sacarose também ocorreu quando os frutos foram descongelados por uma corrente de ar, por aquecimento em microondas e em . água a $35^{\circ} \mathrm{C}$, mas em menor extensão. 0 autor sugeriu que para melhor conservação do açúcar livre, um rápido método dé descongelamento deve ser escolhido.

WESCHE-EBELING \& MONTGOMERY (1990) estudaram - papel da polifenoloxidase (PFO) na degradação da antociani na de morango. Como substrato para a ação da polifenoloxidase foram utilizados D-catequina, pelargonina e cianina los 2 últimos compostos fazem parte da antocianina dos morangos). Os resultados detectaram uma pequena atividade da PFO quando se usou cianina, mostrando que esta enzima tem um papel, embora pequeno, na descoloração da antocianina dos morangos.

A influência da sacarose sobre a estabilidade do pigmento antocianina dos morangos congelados foi estudada por WROLSTAD et al. (1990). Os frutos foram individualmente congelados em leito fluidizado e embalados com 10,20 e $40 \%$ $(p / p)$ de sacarose. As amostras foram armazenadas a $-15^{\circ} \mathrm{C}$ por 3 anos e analisados quanto ao teor de antocianina, quanto à cor e escurecimento. As análises foram feitas com duas repetições e os resultados revelaram que a sacarose tem efeito protetor significativo sobre o conteúdo de antocianinas dos morangos. 


\section{MATERIAL E MÉTODOS}

As atividades desta pesquisa foram conduzidas nas dependências do Departamento de Ciência e Tecnologia Agro industrial da Escola Superior de Agricultura "Luiz de Queiroz" - USP - Campus de Piracicaba e do Instituto de Tecnologia de Alimentos - Seção de Avaliação e Controle de Qualidade - Campinas - SP.

\subsection{Matéria-prima}

No presente trabalho foram utilizadas as seguintes variedades de morango: Sequóia, IAC-Princesa Isabel, Reiko ou Leiko e Chandler.

Foram recebidos no laboratório do Departamento de Ciência e Tecnologia Agroindustrial, lotes de $35 \mathrm{Kg}$ de morango (Fragaria xananassa Duch.) de cada uma das variedades em estudo, provenientes da cidade de Piedade, Estado de são Paulo, através de doação do Sr. Tatuo Sasiki, contactado pelos pesquisadores do Instituto Agronômico de Campinas.

As variedades Sequóia, IAC-Princesa Isabel, Reiko ou Leiko e Chandler foram selecionadas para a realização do presente trabalho de pesquisa, por se tratarem de va- 
riedades em fase de implantação no Estado de são Paulo, não estando, até então, incluídas em pesquisa e por possuirem cạ racterísticas favoráveis para o congelamento conforme resultados obtidos em testes preliminares.

As amostras foram levadas ao laboratório no mesmo dia da colheita e todo material foi processado dentro do periodo máximo de 48 horas, após seu recebimento.

Os frutos processados apresentavam ótimas con dições para consumo "in natura" e estavam no seu ponto ótimo de maturação, quando tinham, portanto, as melhores caracterís ticas sensoriais, quimicas e físicas.

\subsection{Caracterização da matéria-prima}

\subsubsection{Análises físicas}

a) Textura: Para as determinações da textura dos frutos foi utilizado o "Texture Testing System" modelo TP-1, acoplado a um registrador automático de variações de força, operando com célula-padrão de cisalhamento e compressão CS-1, com 10 lâminas de $1 / 8$ polegada de espessura e ângu los $90^{\circ}$. O instrumento estava provido de um anel de prova de $3001 \mathrm{bf}$ e a velocidade de descida do pistão foi de $20 \mathrm{~cm} / \mathrm{min}$.

As amostras foram anteriormente pesadas $150 \mathrm{~g}$ de morangos inteiros, sem os cálices) e colocadas ao acaso na célula-teste. 
Os resultados são apresentados em libra força por grama de amostra.

b) Suculência: Para as determinações de suculên cia dos frutos foi utilizado o "Texture Testing System", empregando a célula-padrão de suculometria CR-1. O instrumento estava provido de um anel de 3000 lbf e a velocidade de desci da do pistão foi de $20 \mathrm{~cm} / \mathrm{min}$.

As amostras foram previamente pesadas $150 \mathrm{~g}$ de morangos inteiros, sem os cálices) e colocadas ao acaso na célula-teste, sendo o volume de suco liberado coletado em proveta graduada de $50 \mathrm{ml}$.

Os dados apresentados correspondem ao volume de suco liberado por grama de amostra, quando submetida a una força máxima de compressão, pelo tempo de 2 minutos.

Os resultados são apresentados em mililitro por grama de amostra.

c) Rendimento: Para as determinações de rendimento da matéria-prima, foram utilizadas amostras de $1000 \mathrm{~g}$ de frutos tomados aleatoriamente dos lotes do material.

Inicialmente os frutos foram pesados em balan ça semi-analitica conforme eram recebidos no laboratório. A seguir, foram limpos, lavados e drenados por 15 minutos e, então, novamente pesados.

Os resultados são apresentados em percentagem do peso da matéria-prima pronta para processamento em rela- 
cão ao peso original da matéria-prima.

Todas as determinações físicas foram efetuadas com três repetições em amostras tomadas aleatoriamente dos lotes das quatro variedades da matéria-prima.

\subsubsection{Análises quỉmicas.}

Para a caracterização química foi retirada, ao acaso, uma amostra de $3 \mathrm{Kg}$ de frutos de cada lote das quatro variedades em estudo e nesse material foram efetuadas as seguintes análises:

a) pH: Foi determinado em potenciômetro Alpha lab, modelo PA-200. Resultados expressos em unidades de $\mathrm{pH}$.

b) Acidez total titulāivel: Foi determinada segundo método de referência-número 22060 da "ASSOcIATION OF OFFICIAL ANALYTICAL CHEMISTS" - AOAC (1975), conforme descrí to a seguir.

Amostras de $10 \mathrm{~g}$ foram trituradas com $90 \mathrm{ml}$ de água destilada e a seguir tituladas rapidamente e sob agitação, com solução $0,1 \mathrm{~N}$ de $\mathrm{NaOH}$, até $\mathrm{pH}=7,0 ;$ a partir deste ponto a titulação prosseguiu lentamente até $\mathrm{pH}=8,1$.

Os resultados foram expressos em percentagem do ácido presente em maior quantidade na matéria-prima que, no caso do morango, é o ácido cítrico.

c) Sólidos solúveis: Expressos em ${ }^{\circ}{ }_{B r i x}$ - foi de terminado em refratômetro Atago, modelo N-1. Resultados expressos em percentagem $(\mathrm{m} / \mathrm{m})$. 
d) Acido ascónbico (Vitamina C): Foi determinado por extração em ácido oxálico e leitura em expectofotômetro. CELM - Modelo E-215 D, segundo o método de referência da "Association Of OfFicial ANALYTiCAL Chemists" - AOAC (1975), conforme descrito a seguir.

Amostras de 50 gramas foram trituradas em liquidificador com $250 \mathrm{ml}$ de ácido oxálico a 4 por mil, durante 3 minutos. A seguir esta mistura foi passada para um balão volumétrico de $500 \mathrm{ml}$. O copo do liquidificador foi lavado com porções de 50ml de ácido oxálico, que eram passadas para o balão volumétrico de $500 \mathrm{ml}$, até completar o volume. A seguir, o conteúdo do balão foi filtrado e $20 \mathrm{ml}$ deste foi pipe tado para um balão volumétrico de $100 \mathrm{ml}$, que teve este volume completado com ácido oxálico 4 por mil. Deste conteúdo, foram então pipetados $10 \mathrm{ml}$ para um béquer de $25 \mathrm{ml}$, que já continha 3ml de solução-tampão (ácido cítrico mais NaOH); a seguir o béquer foi agitado e, então, foi pipetado $5 \mathrm{ml}$ que foi transferido rapidamente para um tubo do espectofotômetro que já continha 5ml de corante (solução 2,6 diclorofenol - indofenol). Usando água destilada para calibrar o espectofotômetro, foi feita uma leitura depois de 15 segundós da mistura e outra quando decorridos mais 15 segundos. Uma terceira lei tura foi feita descolorindo-se totalmente a mistura mediante adição de vitamina $C$ pura sólida. o comprimento de onda utilizado foi de $540 \mathrm{~nm}$. Os teores das amostras foram calculados tomando-se por base uma curva-padrão de vitamina $C$, previamente determinada. 
Os resultados foram expressos em mg de vitami na C por $100 \mathrm{~g}$ de amostra.

e) Deternirasāo da atividade da polifenol oxidase (PFO): A atividade da PFO foi determinada de acordo com a técnica descrita por PONTING \& JOSLYN (1948), com algumas alterações. Amostras de $40 \mathrm{~g}$ de fruto e $160 \mathrm{ml}$ de água destilada gelada $\left(0-4^{\circ} \mathrm{C}\right)$ foram triturados por três minutos em liquidificador. O material assim preparado foi centrifugado (International K) por 15 minutos a 364G. O líquido sobrenadante foi passado para um Erlenmayer de $250 \mathrm{ml}$ com tampa e co locado em banho de gelo picado, para ser utilizado como fonte enzimica (extrato enzimico).

Em outro Erlenmeyer de $250 \mathrm{ml}$ foram adicionados $3 \mathrm{ml}$ de catecol $0,1 \mathrm{M}$ e $96 \mathrm{ml}$ de tampão fosfato $0,2 \mathrm{M}, \quad \mathrm{pH}=$ =6,0 (substrato) que, a seguir, foi deixado em banho-maria a $30^{\circ} \mathrm{C}$ até estabilizar a temperatura. A este substrato foi adi cionado $1 \mathrm{ml}$ do extrato enzímico, sendo então rapidamente homogeneizado; tomaram-se cerca de $10 \mathrm{ml}$ em um tubo de espectro fotômetro, efetuando-se 10 leituras de 1 em 1 minutos, em $425 \mathrm{~nm}$.

O espectrofotômetro usado foi o CELM modelo E-215D, previamente calibrado com água destilada. Como controle para a reação enzímica, foi utilizado um tubo do espec trofotômetro contendo apenas o substrato (catecol e tampão fosfatol. 
Uma unidade da enzima (PFO) foi definida como a quantidade de extrato enzimico que acusou um aumento na ab sorbância de 0,001 unidades por minuto.

f) Deterniracão da atividade da peroxidase: a atividade da peroxidase foi determinada de acordo com a técnica descrita por FERHRMANN \& DIAMOND (1967), com algumas modificações.

Amostras de $40 \mathrm{~g}$ de fruto e $160 \mathrm{ml}$ de ägua destilada gelada $\left(0^{\circ}-4^{\circ} \mathrm{C}\right)$ foram triturados por três minutos em liquidificador. O material assim preparado foi centrifugado (International K) por 15 minutos a $364 \mathrm{~g}$. O liquido sobrenadante foi passado para um Erlenmeyer de $250 \mathrm{ml}$ com tampa e co locado em banho de gelo picado, para ser utilizado como fonte enzímica (extrato enzimico).

Em outro Erlenmeyer de $50 \mathrm{ml}$ foram adicionados $20 \mathrm{ml}$ de tampão fosfato $0,2 \mathrm{M}, \mathrm{pH}=6,0$ e $2 \mathrm{ml}$ do extrato enzímico que, a seguir, foi deixado em banho-maria a $25^{\circ} \mathrm{C}$ até estâ bilizar a temperatura. Após a estabilização, foi adicionado $1 \mathrm{ml}$ de guaiacol $0,58 \mathrm{e}$, em seguida, $1 \mathrm{ml}$ de $\mathrm{H}_{2} \mathrm{O}_{2} 0,08 \%$ sendo, então, rapidamente homogeneizado; tomaram-se, a seguir, 10ml em tubo do espectrofotômetro, efetuando-se 10 leituras de 1 em 1 minuto, em $470 \mathrm{~nm}$.

o espectrofotômetro usado foi o CELM modelo E-215 D, previamente calibrado com água destilada. Como controle para a reação enzímica, foi utilizado um tubo de espec trofotômetro contendo a mistura reativa menos o peróxido de 
hidrogênio (tampão fosfato, extrato enzimico e guaiacol).

Também, no caso da peroxidase, uma unidade da enzima foi definida como a quantidade de extrato enzimico que acusou um aumento na absorbância de 0,001 unidades por minuto.

Todas as determinações quỉmicas foram efetuadas com três repetições em amostras tomadas aleatoriamente dos lotes das quatro variedades da matéria-prima.

\subsubsection{Anätises sensoriais}

As amostras dos lotes das quatro variedades de morango estudadas foram avaliadas subjetivamente quanto à cor, textura e sabor.

As avaliações das amostras foram realizadas por uma equipe de oito provadores, previamente selecionada e treinada para este tipo de avaliação (GIRARDOT et al., 1952; DAWSON, 1964 e MARTIN, 1973). Atributos de qualidade como cor, textura e sabor (notadamente este último), devido à com plexidade inerente aos mesmos, são geralmente avaliados de maneira mais adequada pela análise sensorial (SAWYER, 1971). Os modelos de fichas utilizadas nestas avaliações estão apre sentadas nas Figuras 1,2 e 3.

Para avaliação da cor dos frutos, as amostras foram servidas em pratos de louça branca, os quais foram dis postos aleatoriamente em bandeja de plástico branco, colocada em local com iluminação de luz fluorescente. 
Para avaliação da textura e do sabor, cada amostra foi servida aos provadores em pratos de plástico branco, codificados com números de três dígitos e em cabines individuais iluminadas com luz vermelha, para mascarar a cor dos frutos.

Os dados obtidos foram avaliados estatisticamente através da análise de variância e Teste de Tukey.

\section{AVALIAÇÃO SENSORIAL}

Produto:

Nome:
Tratamento:

Data:

Indique a intensidade da TEXTURA de cada amos tra de acordo com a escala abaixo.

\begin{tabular}{|c|c|c|c|c|c|c|c|c|c|c|}
\hline \multirow{2}{*}{ Amostras } & \multirow{2}{*}{$\begin{array}{l}\text { Muito } \\
\text { Mole } \\
1\end{array}$} & \multicolumn{2}{|c|}{ Mole } & \multicolumn{3}{|c|}{$\begin{array}{l}\text { Nem Mole } \\
\text { Nem Firme } \\
\end{array}$} & \multicolumn{2}{|c|}{ Firme } & \multirow{2}{*}{$\begin{array}{l}\text { Muito } \\
\text { Firme } \\
9\end{array}$} & \multirow{2}{*}{ Observações } \\
\hline & & 2 & 3 & 4 & 5 & 6 & 7 & 8 & & \\
\hline & & & & & & & & & & \\
\hline & & & & & & & & & & \\
\hline & & & & & & & & & & \\
\hline$\cdot$ & & & & & & & & & & \\
\hline & & & & & & & & & & \\
\hline & & & & & & & & & & \\
\hline
\end{tabular}

FIGURA 1. Modelo de ficha utilizada na avaliação sensorial das amostras quanto à textura. 


\section{AVALIACAOO SENSORIAL}

Produto:

Tratamento:

Nome:

Data:

Indique a intensidade do SABOR de cada amostra dea cordo com a escala abaixo:

\begin{tabular}{|c|c|c|c|c|c|c|c|c|c|c|}
\hline \multirow{2}{*}{ Amostras } & \multirow{2}{*}{$\frac{\text { Sem Sabor }}{1}$} & \multicolumn{2}{|c|}{$\begin{array}{l}\text { Sabor } \\
\text { Fraco }\end{array}$} & \multicolumn{3}{|c|}{$\begin{array}{c}\text { Sabor } \\
\text { Moderado }\end{array}$} & \multicolumn{2}{|c|}{$\begin{array}{l}\text { Sabor } \\
\text { Intenso }\end{array}$} & \multirow{2}{*}{\begin{tabular}{|c|}
$\begin{array}{l}\text { Sabor Muito } \\
\text { Intenso }\end{array}$ \\
9
\end{tabular}} & \multirow{2}{*}{ Observações } \\
\hline & & 2 & 3 & 4 & 5 & 6 & 7 & 8 & & \\
\hline & & & & & & & & & & \\
\hline & & & & & & & & & & \\
\hline & & & & & & & & & & \\
\hline & & & & & & & & & & \\
\hline & & & & & & & & & & \\
\hline & & & & & & & & & & \\
\hline
\end{tabular}

FIGURA 2. Modelo de ficha utilizada na avaliação sensorial das amostras quanto ao sabor.

\section{AVALIACAOO SENSORIAL}

Produto:

Nome :
Tratamento:

Data:

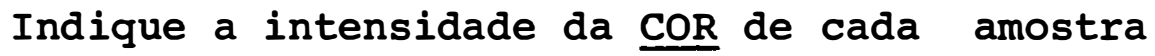
de acordo com a escala abaixo:

\begin{tabular}{|c|c|c|c|c|c|c|c|c|c|c|}
\hline \multirow{2}{*}{ Amostras } & \multirow{2}{*}{$\frac{\text { Sem Cor }}{1}$} & \multicolumn{2}{|c|}{$\begin{array}{l}\text { Cor } \\
\text { Fraca }\end{array}$} & \multicolumn{3}{|c|}{$\begin{array}{l}\text { Cor } \\
\text { Moderada }\end{array}$} & \multicolumn{2}{|c|}{$\begin{array}{c}\text { Cor } \\
\text { Intensa } \\
\end{array}$} & \multirow{2}{*}{\begin{tabular}{|c|}
$\begin{array}{c}\text { Cor Muito } \\
\text { Intensa }\end{array}$ \\
9
\end{tabular}} & \multirow{2}{*}{ Observações } \\
\hline & & 2 & 3 & 4 & 5 & 6 & 7 & 8 & & \\
\hline & & & & & & & & & & \\
\hline & & & & & & & & & & \\
\hline & & & & & & & & & & \\
\hline & & & & & & & & & & \\
\hline & & & & & & & & & & \\
\hline & & & & & & & & & & \\
\hline
\end{tabular}

FIGURA 3. Modelo de ficha utilizada na avaliação sensorial das amostras quanto à cor. 


\title{
4.3. Processamento
}

As operações utilizadas no processamento dos morangos estão representadas no fluxograma constante da Figu ra 4 .

Após o recebimento no laboratório, de cada lo te de matéria-prima, foram inicialmente removidos os cálices dos frutos que em seguida foram lavados, drenados por $15 \mathrm{mi}-$ nutos e cortados ao meio. A seguir, o lote de matéria-prima foi subdividido em porções de peso equivalente, às quais foram aplicados os tratamentos esquematizados na Figura 5.

\author{
Recebimento da matéria-prima \\ $\downarrow$ \\ Remoção do cálice - manualmente \\ $\downarrow$ \\ Seleção da matéria-prima \\ Lavagem com água à temperatura ambiente \\ $t$ \\ Drenagem d'água \\ Tratamentos de pré-congelamento \\ Retirada de amostras \\ ! \\ Repouso por 30 minutos \\ Acondicionaménto em latas \\ $t$ \\ Congelamento \\ $\downarrow$ \\ Armazenamento congelado
}

FIGURA 4. Fluxograma das operações utilizadas no processamento dos morangos. 
VARIEDADE

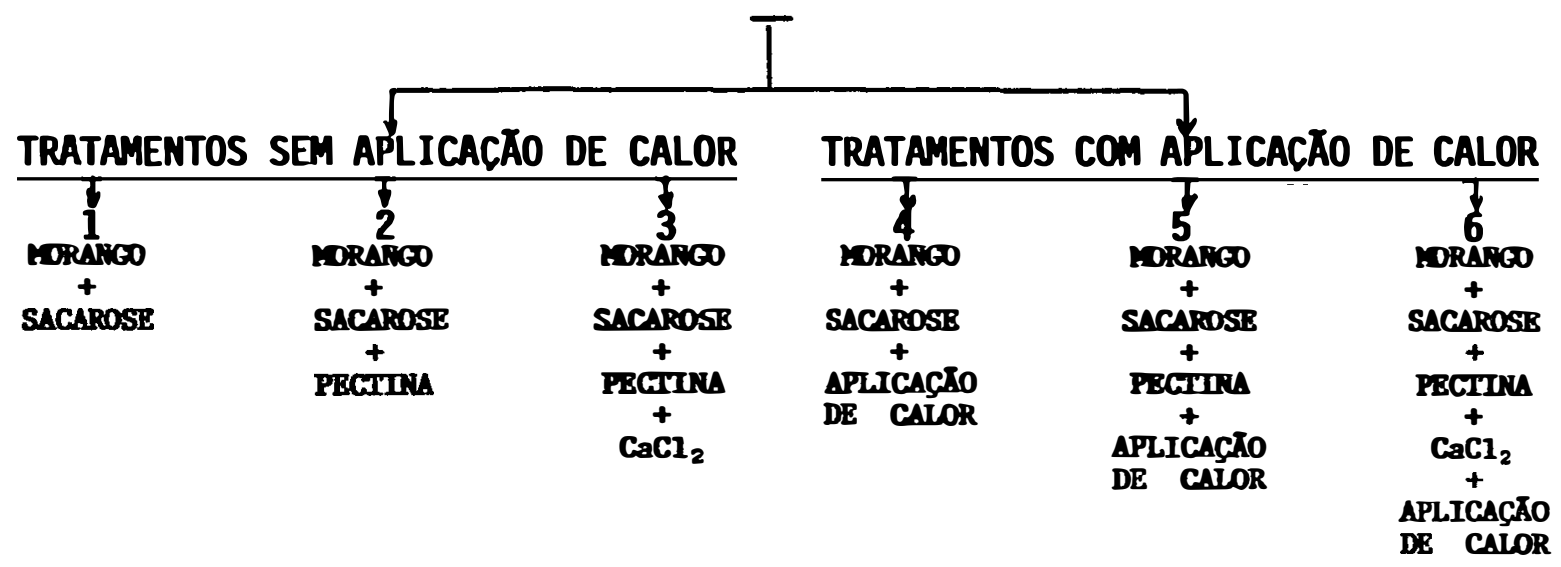

FIGURA 5. Esquema dos tratamentos de pré-congelamento aos quais os morangos foram submetidos.

\subsubsection{Tratamentos de pré-congelamento}

Os frutos de cada variedade de morango em estudo foram submetidos aos seguintes tratamentos de pré-conge lamento:

\section{A. TRATAMENTOS SEM APLICACÃO DE CALOR}

1. MORAREO + SACAROSE

Antes do congelamento, os morangos preparados foram misturados com sacarose, na proporção de 4:1 em relação ao peso dos frutos enlatados, permanecendo em repouso por 30 minutos e congelados.

\footnotetext{
2. HORAMGO + SACAROSE + PECTINA

Os morangos preparados foram misturados com
} sacarose na proporção de 4:1 e com 0,5q de pectina em rela 
cão ao peso dos frutos enlatados. A pectina, antes de ser adicionada ao produto foi misturada a $50 \mathrm{~g}$ do açúcar para eví tar a formação de grumos. O produto permaneceu em repouso por 30 minutos e a seguir, foi congelado.

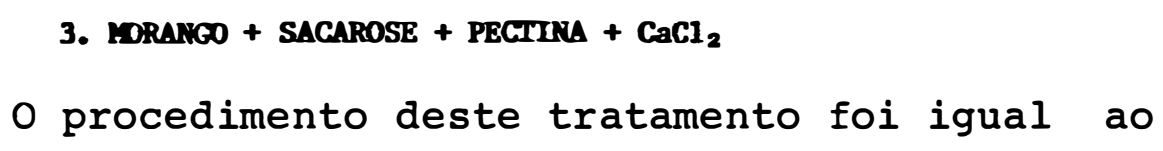
anterior, porém, com adição de cloreto de cálcio na proporção de 0,28 em relação ao peso dos frutos, juntamente com a pectina.

\section{B. TRATAMENTOS COM APLICAÇĀO DE CALOR}

\section{HORAKGO + SACAROSE}

Após o preparo e a adição de sacarose na proporção 4:1 em relação ao peso dos frutos, os morangos foram aquecidos a $85^{\circ} \mathrm{C} / 15$ minutos. Em seguida, foram imediatamente resfriados a $40^{\circ} \mathrm{C}$, enlatados, permanecendo em repouso por 30 minutos e congelados.

\section{MORANGO + SACAROSE + PECTINA}

Este tratamento seguiu $\circ$ mesmo procedimento que 0 anterior, porém, com a adição de 0,58 de pectina em re lação ao peso dos frutos, conforme citado no item 4.3.1.A.2.

\footnotetext{
6. HORANCO + SACAROSE + PEGITINA + $\mathrm{CaCl}_{2}$

Este tratamento seguiu o mesmo procedimento
} que o anterior, porém, com a adição de cloreto de cálcio na 
proporção de 0,28 em relação ao peso dos frutos, conforme cí tado no item 4.3.1.A.3.

\subsubsection{Acondicionamento}

o acondicionamento do material foi realizado em latas metálicas de folha-de-flandres, com capacidade de $450 \mathrm{~g}(74,6 \times 95,2 \mathrm{~mm})$, revestidas internamente com verniz epó xi, o que se faz necessário, devido à acidez do produto.

\subsubsection{Congelamento e armazenamento congelado}

O congelamento foi levado a efeito em congela dor a $-25^{\circ} \mathrm{C}$, onde as amostras permaneceram armazenadas duran te um periodo de 6 meses. O material processado foi analisado aos 45, 90, 135 e 180 dias de armazenamento congelado.

\subsection{Avaliação do produto final}

Para avaliar a qualidade dos morangos congela dos, assim como determinar qual a variedade que melhor se adaptou ao processamento e à eficiência dos tratamentos de pré-congelamento, aos quais os frutos foram submetidos, foram realizadas análises físicas, químicas e sensoriais.

Para a realização das diversas análises, o pro duto congelado foi retirado do congelador e colocado em refrigerador à temperatura de $5^{\circ} \mathrm{C}$ por um periodo de 12 horas, para que ocorresse o descongelamento de forma gradativa, pois uma mudança brusca de temperatura poderia acarretar mudanças 
indesejáveis ao produto, notadamente na sua textura. A seguir, o fruto (parte sólida) e o líquido exsudado (parte liquida) foram separados através de drenagem em peneira US-Tyler $\mathrm{n}: 8$ (abertura da malha 2,38mm), durante um periodo de $2 \mathrm{~min}$, medidos em cronômetro.

\subsubsection{Análises físicas}

a) Textura: para as determinações da textura dos frutos foi utilizado o "Texture Testing System", conforme descrito no item 4.2.1.a.

As amostras anteriormente descongeladas e dre nadas foram pesadas (50g de morangos) e colocadas ao acaso na célula-teste.

Os resultados foram apresentados em libra for ça por grama de amostra.

b) Suculêrcia: conforme descrito no item 4.2.1.b.

Os dados apresentados correspondem ao volume de suco liberado por grama de amostra, quando submetida a uma força máxima de compressão, por um tempo de 2 minutos.

Os resultados são apresentados em mililitro por grama de amostra.

c) Perda de liquido por exsudação: para as determi nações de perda de líquido por exsudação, amostras de $170 \mathrm{~g}$ (quantidade correspondente ao conteúdo de uma lata do produ- 
to congelado), previamente descongeladas, foram drenadas em peneira US-Tyler n.8 (abertura da malha 2,38mm), por um periodo de 2 minutos.

Os resultados foram expressos em $g$ líquido exsudado/g da amostra.

d) Deterninação objetiva da cor: as análises da cor do fruto foram realizadas com amostras de morangos das quatro variedades em estudo. Estas amostras foram lavadas em água corrente e após remoção dos pedúnculos e dos cálices flo rais, os frutos foram acondicionados em sacos plásticos e congelados. As determinações de cor não foram realizadas com os frutos "in natura", porque o equimamento de análises se encontrava em reparos. Assim, os frutos congelados sem sofrer qualquer tipo de tratamento de pré-congelamento foram analisados juntamente com o produto final, aos 180 dias de armazenamento congelado. Esta amostra sem nenhum tratamento será denominada referência.

Para a realização das análises de cor, as amos tras foram descongeladas à temperatura ambiente. Após o descongelamento, o líquido exsudado foi separado dos frutos por drenagem em peneira US-Tyler n.8 (abertura da malha 2,38mm). o líquido exsudado foi, em seguida, separado das sementes e eventuais partículas em suspensão e submetido à vácuo para eliminar os gases presentes.

A leitura de cor das amostras de frutos ou de líquido exsudado foi feita por reflexão em espectrofotômetro 
CONCOR 1500 Plus, calibrado com a configuração DREOL, ângulo de $10^{\circ}$, sistema de medição $\mathrm{L}$ a b da CIE e iluminante $C$.

- Cor dos frutos: para esta determinação os frutos foram arranjados em cápsula de fundo de vidro óptico de maneira a construir uma superficie o mais uniforme possivel. A espessura das amostras foi tal de maneira que se comprovou a opacidade das mesmas.

- Cor do liquido exsudado: foi determinada utị lizando-se amostras com espessura de $4 \mathrm{~mm}$ e anteparo branco $\left(L^{*}=91,28 ; a^{*}=-1,41\right.$ e $\left.b^{*}=3,00\right)$, de modo que a luz incidente atravessasse a amostra, refletisse no fundo e retornasse para ser analisada no fotodetector do aparelho. A determinação da espessura da amostra foi feita em testes preliminares.

A diferença total de cor dos frutos e do liquido exsudado de cada tratamento, em relação à referência (fruto e liquido exsudado), foi obtida por meio da equação.

$$
\begin{aligned}
& E=\sqrt{(\Delta \mathrm{L})^{2}-(\Delta \mathrm{a})^{2}+(\Delta \mathrm{b})} \\
& \text { onde: } \begin{aligned}
\Delta \mathrm{L}=\mathrm{L}_{\mathrm{R}}-\mathrm{L}_{\mathrm{T}} \\
\Delta \mathrm{a}=\mathrm{a}_{\mathrm{R}}-\mathrm{a}_{\mathrm{T}} \\
\Delta \mathrm{b}=\mathrm{b}_{\mathrm{R}}-\mathrm{b}_{\mathrm{T}} \\
\mathrm{e} \quad \mathrm{R}=\text { referência } \\
\mathrm{T}=\text { tratamentos }(1,2,3,4,5,6)
\end{aligned}
\end{aligned}
$$

Todas as determinações físicas realizadas no produto final foram efetuadas com três repetições em amostras 
tomadas aleatoriamente, dos lotes de produto congelado das variedades em estudo. As análises de cor foram feitas somente aos 180 dias do armazenamento congelado.

\subsubsection{Análises químicas}

Para a caracterização química do produto final, foram retiradas amostras do produto descongelado que consistiam em parte sólida (frutos) e parte líquida (líquido exsudado), de cada um dos seis diferentes tratamentos de pré -congelamento, aos quais foi submetida a matéria-prima. Nestas amostras foram efetuadas as seguintes análises:

a) pH: conforme descrito no item 4.2.2.a.

b) Acidez total titulävel: conforme descrito no item 4.2.2.b.

c) Sólidos solúveis: conforme descrito no item $4 \cdot 2 \cdot 2 \cdot c$.

d) Acido ascōrbico (Vitamina $C$ ): confonme descr $\underline{i}$ to no item 4.2.2.d.

Todas as determinações químicas realizadas no produto final foram efetuadas com três repetições em amostras tomadas aleatoriamente, dos lotes de produto congelado das variedades em estudo.

4.4.3. Análises sensoriais

As amostras dos seis diferentes tratamentos de 
pré-congelamento das quatro variedades de morango em estudo foram descongeladas conforme anteriormente descrito no item 4.4 e avaliadas subjetivamente quanto à cor, textura e sabor, de acordo com o descrito no item 4.2.3.

Os dados obtidos foram analisados estatistica mente através do delineamento de blocos casualizados com par celas subdivididas, tipo "split-plot" (SHIROSE, 1985). 


\section{RESULTADOS E DISCUSSĀO}

\subsection{Caracterização da matéria-prima}

\subsubsection{Análises físicas}

Os resultados da avaliação objetiva dos atributos físicos (suculência, textura e rendimento) estão apresentados na Tabela 1.

Segundo HUDSON et al. (1977), a suculência é um atributo físico dos frutos, inversamente ligado à sua tex tura, ou seja, quanto mais firme for um fruto, menos suculen to ele será, em termos de partes comestíveis dos frutos.

Os valores de suculência apresentados pelas variedades em estudo não diferiram estatisticamente entre si, - que pode ser observado na Tabela 1. A variedade IAC-Princesa Isabel apresentou a maior suculência $(1,86 \mathrm{ml} / \mathrm{g})$ e uma das menores texturas $(0,64 \mathrm{lbf} / \mathrm{g})$, ao passo que a Chandler se apresentou com a menor suculência $(0,50 \mathrm{ml} / \mathrm{g})$, porém com a me lhor textura $(1,471 \mathrm{bf} / \mathrm{g})$. Estas observações estão mais ou me nos de acordo com os estudos de HUDSON et al. (1977).

Na Tabela 1, também estão apresentados os resultados da avaliação objetiva da textura obtidos através da 
medida de resistência dos frutos ao cisalhamento. Estes resultados mostraram que a variedade Chandler possui a melhor textura $(1,471 \mathrm{bf} / \mathrm{g})$ diferindo significativamente das demais variedades em estudo. PASSOS (1982) relatou em seu trabalho valores médios de textura variando de $0,93-1,651 \mathrm{bf} / \mathrm{g}$, podendo-se concluir que as variedades em estudo apresentaram valo res semelhantes quanto a este importante atributo.

TABELA 1. Caracteristicas físicas das variedades de morango "in natura" (matéria-prima).

\begin{tabular}{|c|c|c|c|}
\hline \multirow{2}{*}{ Variedades } & \multirow{2}{*}{$\begin{array}{l}\text { Média das } \\
\text { Suculencja } \\
(\mathrm{mlg} / \mathrm{g})\end{array}$} & \multicolumn{2}{|c|}{ Análises (3 repeticōes) } \\
\hline & & $\begin{array}{l}\text { Textura } \\
(1 \mathrm{bf} / \mathrm{g})\end{array}$ & Rendimento \\
\hline IAC-Princesa Isabel & 0,62 & $0,64^{A}$ & $95,0 \%$ \\
\hline Reiko & 0,52 & $1,00^{\mathrm{AB}}$ & $93,0 \%$ \\
\hline Sequōia & 0,52 & $0,61^{A}$ & $91,5 \%$ \\
\hline Chandler & 0,50 & $1,47^{C}$ & $93,5 \%$ \\
\hline F (amostras) & $3,10^{\text {n.s. }}$ & $36,04^{\star \star}$ & $4,66^{\text {n.s. }}$ \\
\hline F (variedades) & $3,41^{\text {n.s. }}$ & $1,39^{\text {n.s. }}$ & $2,93^{\text {n.s. }}$ \\
\hline
\end{tabular}

As percentagens de rendimento das quatro variedades estudadas (Tabela 1) mostram que, para cada $1.000 \mathrm{~g}$ de morango "in natura", 950g da IAC-Princesa Isabel, 930g de Reiko, 915g da Sequóia e $935 \mathrm{~g}$ da Chandler foram utilizados para o processamento, o que representa um alto aproveitamen 
to e boa qualidade da matéria-prima, com ausência de frutos amassados, machucados ou deteriorados por microrganismos. $\underline{\mathrm{Ob}}$ servando-se a Tabela 1, conclui-se que as variedades Reiko e Sequóia apresentaram rendimentos menores que as variedades Chandler e IAC-Princesa Isabel, porém os resultados não dife riram estatisticamente entre si.

\subsubsection{Análises químicas.}

Na Tabela 2, são apresentados os resultados das determinações do teor de vitamina $C, \mathrm{pH}$, acidez total tí tulável e do teor de sólidos solúveis da matéria-prima.

Os resultados referentes ao teor de vitamina C constatados nas quatro variedades de morangos estudadas, IAC-Princesa Isabel $148 \mathrm{mg} / 100 \mathrm{~g}$, Reiko $162 \mathrm{mg} / 100 \mathrm{~g}$, Sequóia $177 \mathrm{mg} / 100 \mathrm{~g}$ e Chandler $152 \mathrm{mg} / 100 \mathrm{~g}$, mostraram-se altos, quando comparados com os dados obtidos por: FIK \& MACURA (1988), que constataram 33,2mg/100g; GUEGOV et al. (1982) que estudaram 12 variedades diferentes de morangos e encontraram valores entre 19,9 e $48,7 \mathrm{mg} / 100 \mathrm{~g}$; FUSTER et al. (1982) que investigaram as variedades Tioga, Tuff, Tioga-Salamanca e Cambridge e encontraram 40,89, 93,13, 68,92 e 78,46mg/100g respectivamente; PASCHOALINO (1977) que constatou $46,0 \mathrm{mg} / 100 \mathrm{~g}$ para variedades IAC-2712; E PASCHOALINO et al. (1973/74), que estudando 12 variedades, encontraram um intervalo de valores que variou entre 24 e $64 \mathrm{mg} / 100 \mathrm{~g}$. 
Comparando as quatro variedades entre si (Tabela 2), através das diferenças entre as médias, verifica-se que a variedade Sequóia diferiu significativamente das demais, apresentando um elevado teor de vitamina C (177mg/100g).

Deve-se ressaltar que um alto teor de vitamina $C$ é uma característica desejável e de muita importância do ponto de vista nutricional dos alimentos.

A acidez das variedades em estudo foi analisa da em termos de valores de $\mathrm{pH}$ e acidez total titulável (g áci do citrico/100g de frutol. Ambos os resultados são apresenta dos na Tabela 2 .

Os valores de $\mathrm{pH}$ obtidos foram, em geral, inferiores aos relatados por PASCHOALINO (1977) que estudou a variedade IAC-2712. Comparando com variedades européias estu dadas por GARROTE \& BERTONE (1975), verifica-se que as varie dades estudadas IAC-Princesa Isabel, Reiko, Sequóia e Chandler apresentaram valores de $\mathrm{pH}$ maiores e acidez total titulável menores que os encontrados por aqueles autores.

Comparando as quatro variedades estudadas, atravês das diferenças entre as médias, verifica-se que as variedades IAC-Princesa Isabel e Reiko diferiram significatí vamente das variedades Sequóia e Chandler, quanto ao pH, porém não apresentaram diferenças quanto à acidez total titulá vel (Tabela 2).

As variedades estudadas apresentaram valores de sólidos solúveis (Brix) variando de 6,6 (Sequóia) a 8,78 
(Reiko). O teor de sólidos solúveis é um parâmetro importante, pois é o indicativo do grau de doçura dos frutos. Os resultados obtidos são concordantes com os valores médios cita dos por FUSTER et al. (1982) para quatro variedades européias (Tioga, Tuff, Tioga-Salamanca e Cambridge) e por SELVARAJ et al. (1976) para 20 variedades americanas, com valores de sólidos solúveis variando de 4,96 a $12,04 \%$.

Comparando as variedades estudadas (Tabela 2), observa-se que a variedade Sequóia diferiu estatisticamente das demais, apresentando o teor de sólidos solúveis mais bai xo.

Nas condições em que foram analisadas, nenhuma das quatro variedades estudadas apresentou atividade das enzimas polifenoloxidase e peroxidase.

TABELA 2. Caracteristicas químicas das variedades de morango "in natura" (matéria-prima).

\begin{tabular}{|c|c|c|c|c|}
\hline \multirow{2}{*}{ Variedades } & \multicolumn{4}{|c|}{ Média das Anālises ( 3 repetições) } \\
\hline & $\begin{array}{c}\text { Teor de Vitamina C } \\
(\mathrm{mg} / 100 \mathrm{~g})\end{array}$ & $\mathrm{pH}$ & $\begin{array}{l}\text { Acidez lotal } \\
\text { Titulavel (\%) }\end{array}$ & Brix \\
\hline IAC-Princesa Isabe & $148^{\mathrm{a}}$ & $3,71^{a}$ & 0,73 & $8,2^{\mathrm{a}}$ \\
\hline Reiko & $162^{b}$ & $3,62^{\mathrm{a}}$ & 0,94 & $8,7^{\mathrm{a}}$ \\
\hline Sequóia & $177^{\mathrm{b}}$ & $3,36^{\mathrm{b}}$ & 1,00 & $6,6^{\mathrm{b}}$ \\
\hline Chandler & $152^{a, b}$ & $3,39^{b}$ & 0,92 & $0,1^{\mathrm{a}}$ \\
\hline $\mathrm{F}$ (amostras) & $0,46^{\mathrm{n} \cdot \mathrm{s}}$ & $0,47^{\text {n.s. }}$ & $0,25^{\mathrm{n} \cdot \mathrm{s}}$. & $0,47^{\text {n.s. }}$ \\
\hline F (variedades) & $26,63^{\star}$ & $30,91^{\star}$ & $3,24^{\text {n.s. }}$ & $9,53^{\star \star}$ \\
\hline
\end{tabular}




\subsubsection{Análises sensoriais}

A Tabela 3 apresenta os resultados da avaliação subjetiva da cor, textura e sabor das amostras das quatro variedades de matéria-prima em estudo.

A avaliação subjetiva da cor externa dos frutos (Tabela 3) mostrou que a variedade Chandler diferiu das variedades IAC-Princesa Isabel e Sequóia e não apresentou di. ferença significativa quando comparada com a variedade Reiko, ou seja, as variedades Chandler e Reiko foram consideradas de "cor intensa" pela equipe de provadores.

Quanto à avaliação da textura (Tabela 3), os resultados mostraram que a Chandler diferiu significativamen te das demais variedades, sendo, portanto, considerada em ter mos de firmeza a melhor, seguindo-se das variedades IAC-Prin cesa Isabel, Sequóia e Reiko em ordem decrescente. Particularmente, para a variedade Chandler houve concordância com a avaliação objetiva, confirmando o que foi discutido no item 5.1 .1 .

A doçura e a acidez são representadas pelas me didas de sólidos solúveis (Brix) e de acidez total titulável (ATT), respectivamente, e a relação de Brix/ATT, denominada pelo termo "ratio", influencia diretamente o sabor dos frutos, conforme NELSON et al. citado por PASSOS (1982).

Os resultados da avaliação subjetiva (Tabela 3) mostraram que, quanto ao sabor, as variedades Chandler e Reiko diferiram significativamente da variedade IAC-Princesa 
Isabel, sendo que a Reiko foi a preferida pelos provadores obtendo a maior nota para este atributo $(7,4)$, a qual corres ponde a "sabor intenso" na escala utilizada (Figura 2).

As variedades Chandler, Sequóia e IAC-Princesa Isabel foram consideradas de "sabor moderado" pela equipe de provadores. De acordo com os resultados de ATT e Brix (Ta bela 2), observa-se que a variedade IAC-Princesa Isabel apre sentou o maior valor para a relação Brix/ATT, mas também apre sentou o menor valor para o sabor (Tabela 3 ).

TABELA 3. Análise sensorial das variedades de morango "in natura".

\begin{tabular}{lccc}
\hline \multirow{2}{*}{ Variedades } & \multicolumn{3}{c}{ Médias das Avaliaçōes (8 provadores) } \\
\cline { 2 - 4 } & \multicolumn{1}{c}{ Cor } & Textura & Sabor \\
\hline IAC-Princesa Isabel & $5,0^{\mathrm{A}}$ & $6,6^{\mathrm{A}}$ & $5,6^{\mathrm{A}}$ \\
Reiko & $7,5^{\mathrm{B}, \mathrm{C}}$ & $5,9^{\mathrm{A}, \mathrm{B}}$ & $7,4^{\mathrm{B}, \mathrm{C}}$ \\
Sequöia & $6,5^{\mathrm{A}, \mathrm{B}}$ & $6,1^{\mathrm{A}, \mathrm{B}}$ & $6,5^{\mathrm{A}, \mathrm{B}}$ \\
Chandler & $8,4^{\mathrm{C}}$ & $8,5^{\mathrm{C}}$ & $6,6^{\mathrm{B}, \mathrm{C}}$ \\
\hline F (amostras) & $22,42^{*}$ & $4,55^{\star \star}$ & $3,29^{\star \star}$ \\
F (provadores) & $4,87^{\star \star}$ & $1,78^{\mathrm{n} . \mathrm{s} .}$ & $4,12^{\star \star}$ \\
\hline
\end{tabular}

* = significativo ao nivel de $5 \%$.

** = significativo ao nivel de $1 \%$. n.s.= não significativo.

Desta forma, além do gosto doce e da acidez, outras caracteristicas sensoriais, como odor e cor, podem in fluenciar na aceitação dos frutos. 
De forma geral, os resultados obtidos pela avaliação sensorial das variedades de morango em estudo são semelhantes aos obtidos por PASCHOALINO (1977) \& PASSOS (1982) .

\subsection{Avaliação do produto final}

\subsubsection{Análises físicas}

As Tabelas 4, 5 e 6 apresentam os resultados da avaliação objetiva da suculência, perda de líquido por ex sudação e textura dos morangos congelados das variedades em estudo. Os resultados da análise objetiva da cor estão apresentados nas Figuras 6,7 e 8 .

Dentre as alterações que ocorrem em frutos congelados, as físicas são as mais indesejáveis. Estas alterações resultam em modificações no sistema coloidal, colapso celular, amoledimento de formato, de peso e do volume natural do fruto (TEIXEIRA NETO, 1979).

Como já foi anteriormente citado, a suculência é um atributo físico dos frutos frescos inversamente pro porcional à textura destes, ou seja, quanto mais firme for o fruto fresco, menos suculento ele será. Quando os frutos são congelados e descongelados, esta propriedade é invertida, ou seja, o fruto que for menos firme e em conseqüência mais suculento "in natura" se tornará pouco suculento quando descon gelado, pois irá perder grande parte de seu teor de água no descongelamento (HUDSON et al., 1975b). Dentre as quatro va- 
riedades de morango em estudo, a Sequóia mostrou-se a menos suculenta, assim como a de menor firmeza (Tabelas 4 e 6, res pectivamente). Para a variedade Reiko (Tabela 4), o tratamen to 1 diferiu dos tratamentos 4,5 e 6 e os demais tratamentos não diferiram entre si; para a variedade Sequóia, o tratamento 2 diferiu dos tratamentos 4,5 e 6 e o tratamento 3 diferiu do 6 , sendo que os demais tratamentos não diferiram entre si; para a Chandler, os tratamentos 1 e 2 foram estatisticamente diferentes dos tratamentos 4,5 e 6 e os demais tratamentos não diferiram entre si; jā para a variedade IAC-Princesa Isabel, os tratamentos 4, 5 e 6 diferiram estatisticamente dos tratamentos 1,2 e 3. Para as quatro variedades, em todos os períodos de avaliação, a aplicação de calor (tratamentos 4,5 e 6 ) diminuiu a suculência dos frutos (Tabela 4). Também pode-se verificar que o tratamento 2 (fruto, sacarose e pectina) apresentou-se como o melhor, em termos de suculência dos frutos.

Com relação à perda de líquido por exsudação (Tabela 5) as variedades estudadas (com exceção da Chandler) apresentaram diferença estatística significativa entre os tra tamentos 1, 2 e 3 (sem aplicação de calor) e os tratamentos 4,5 e 6 (com aplicação de calor), apresentando estes últimos naior perda de líquido por exsudação. Para as quatro diferentes épocas de avaliação, as variedades de morango em es tudo, mantiveram-se estáveis, conforme pode ser verificado na Tabela 5, ou seja, o valor de $F$ não foi significativo para épocas de avaliação (exceto para a variedade Sequóia). 


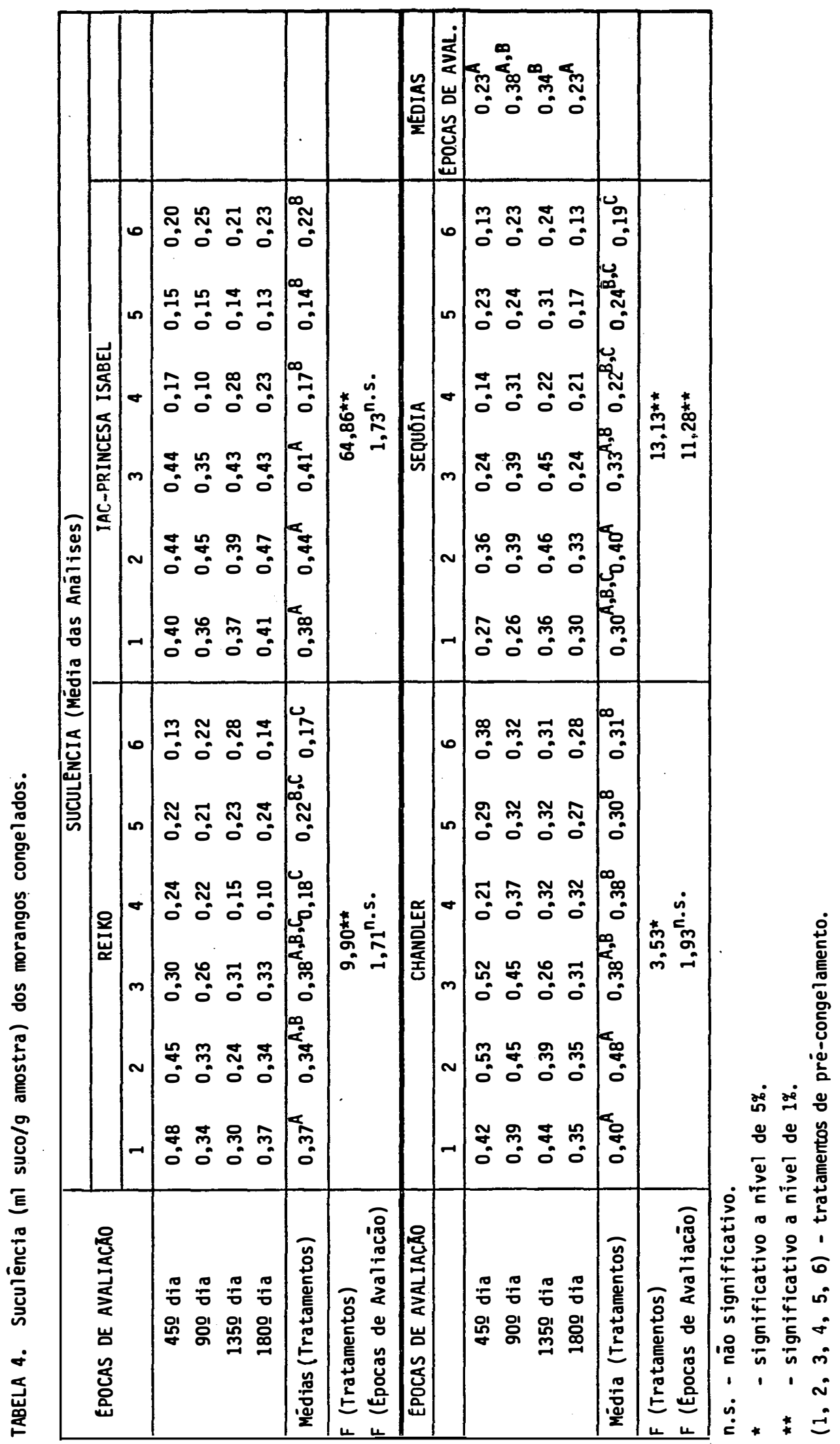


Entre as variedades IAC-Princesa Isabel, Sequóia, Reiko e Chandler, a variedade Chandler apresentou menor perda de líquido por exsudação (Tabela 5), sendo, portan to, a variedade que no final de 180 dias de armazenamento con gelado apresentou menores danos na aparência ou formato natu ral do fruto. Isto aconteceu porque a Chandler foi a varieda de que apresentou a melhor textura no produto final (Tabela 6).

Deve-se ressaltar, também, que o tratamento 3 , que utilizou frutos + sacarose + pectina + cálcio foi eficien te para todas as variedades em estudo, minimizando a perda de liquido por exsudação, conforme pode ser verificado na Tá bela 5. Este fato pode ser explicado pela interação pectinal /cálcio, dando origem ao pectato de cálcio na forma de uma pelicula protetora ao redor dos frutos, diminuindo a perda de liquido.

Pela TAbela 6 pode-se observar que os tratamentos de pré-congelamento, quando comparados entre si, não provocaram efeitos significativos na textura das variedades Reiko, IAC-Princesa Isabel e Sequóia. Apenas a variedade Chan dler foi influenciada pelos tratamentos de pré-congelamento, sendo que os melhores valores de textura foram obtidos nos frutos submetidos ao tratamento 6 (fruto + sacarose + pectina + cálcio + aplicação de calor). Isto pode ser explicado pela interação pectina/cálcio, originando o pectato de cálcio na forma de uma película protetora ao redor do fruto, como já foi anteriormente citado. Esta película de pectato 


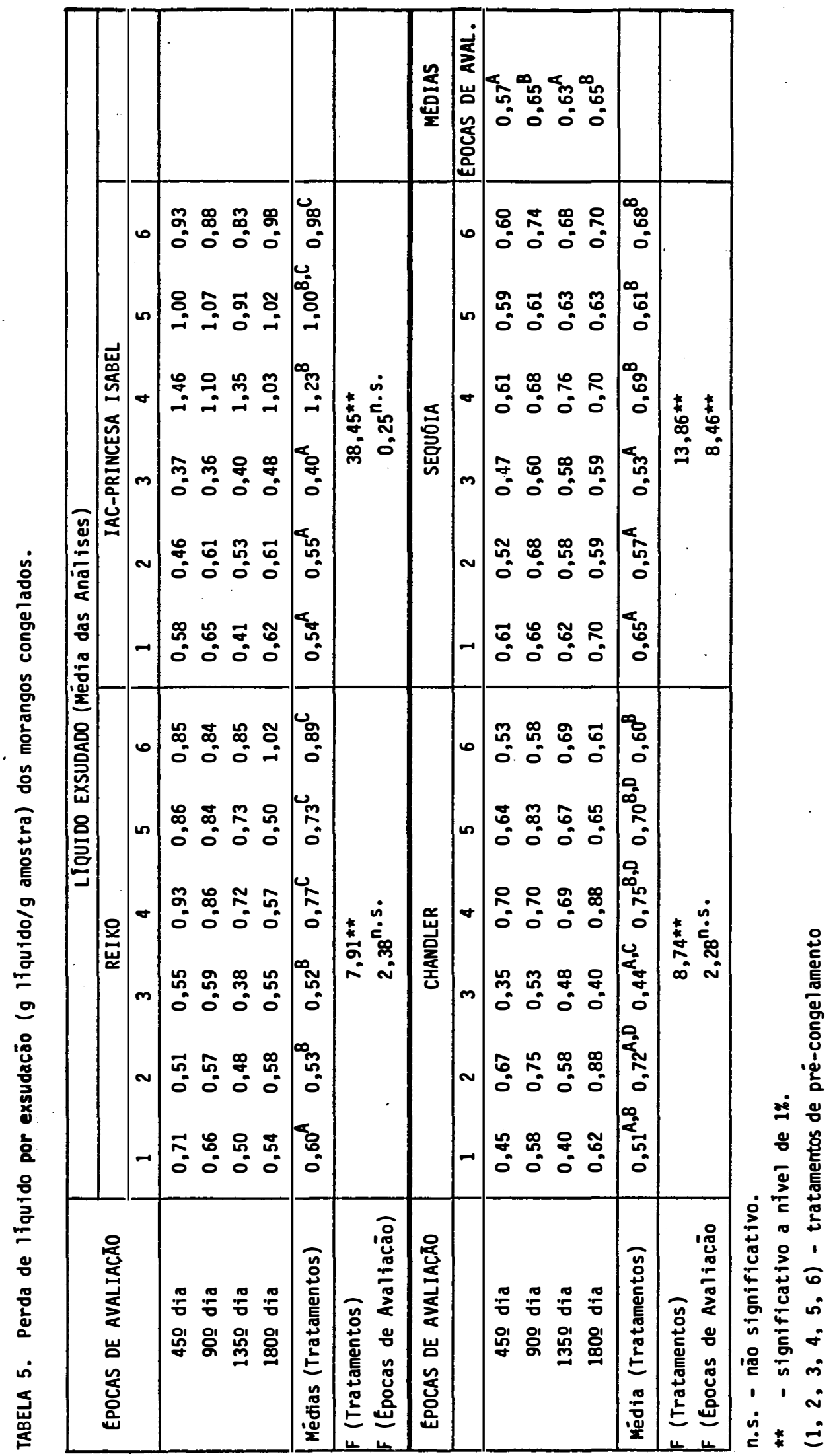


de cálcio forma-se de maneira mais intensa, quando na presen ça de calor, conforme ocorreu no tratamento 6 . Os maiores va lores de textura obtidos neste caso devem-se à resistência que a película de pectato de cálcio oferece ao cisalhamento dos frutos, nas avaliações de textura dos frutos.

A qualidade dos frutos foi influenciada pelo periodo de armazenamento congelado. De maneira geral, confor me pode ser observado na Tabela 6 , para todas as variedades e todos os tratamentos de pré-congelamento, os melhores valores de textura obtidos foram aos 135 dias de armazenamento congelado.

Para a variedade Chandler, os valores de textura obtidos para a matéria-prima e para o produto final foram os maiores, quando comparados com as outras variedades em estudo, mas se mostraram semelhantes aos dados obtidos por SISTRUNK \& MOORE (1967) e por MAIN et al. (1986) para a varie dade Cardinal, também submetida a diferentes tratamentos de pré-congelamento.

Porém, pode-se observar que nas Tabelas 1 e 6 a textura dos frutos congelados apresentou maiores valores que a dos frutos "in natura", para todas as variedades em es tudo, o que pode ser explicado através do aumento de elasticidade da pele dos frutos, que ocorre com a exsudação do liquido do interior destes durante o descongelamento, provocan do uma resistência maior ao cisalhamento, conforme ocorre nas avaliações de textura dos frutos. 


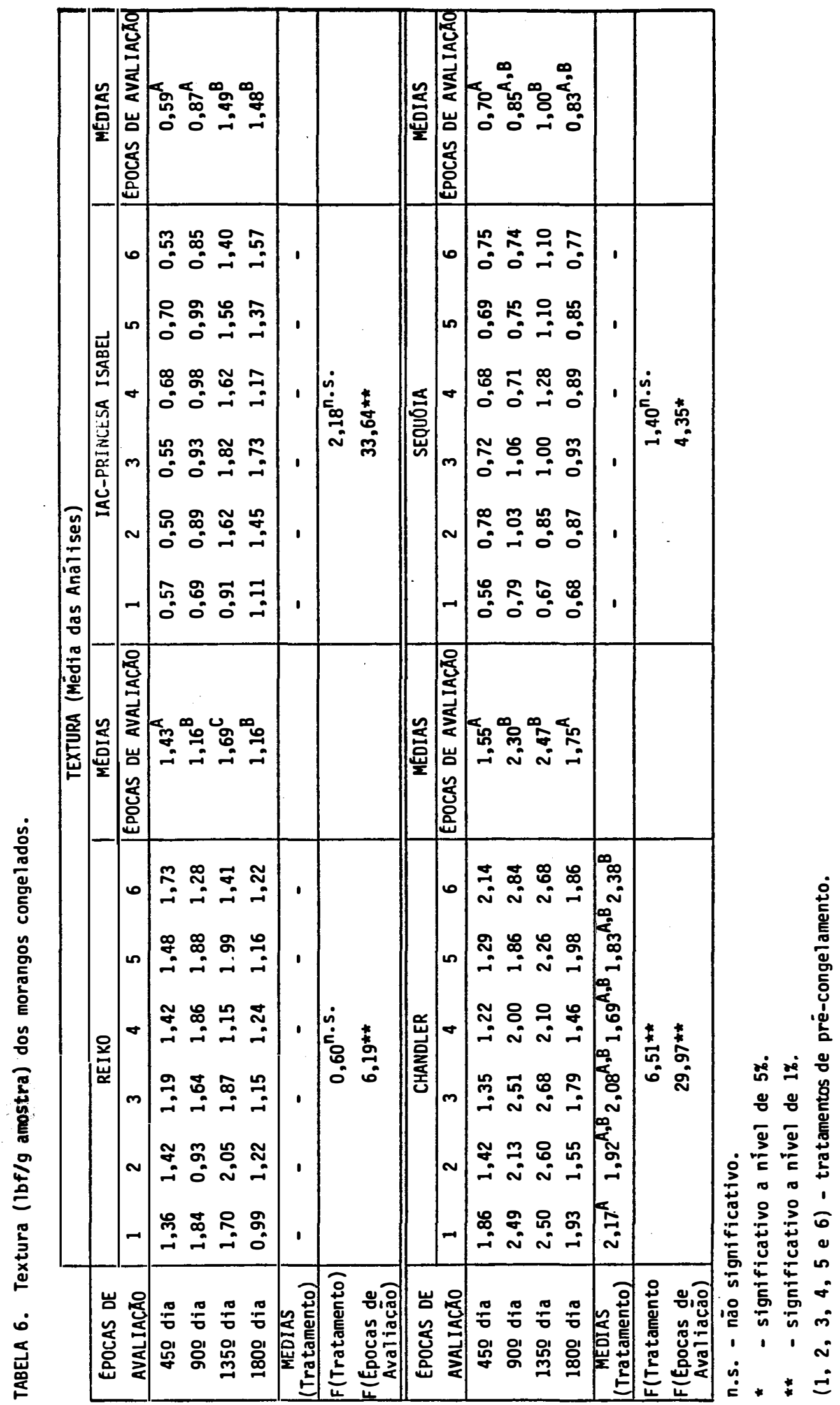


Os resultados da análise objetiva da cor dos frutos (parte sólida) e do liquido exsudado, sem tratamento, são apresentados na Figura 6. Estas amostras foram denominadas de referência.

Pela Figura 6 observa-se que houve variação na cor dos frutos entre as variedades estudadas, especialmente no liquido exsudado. Os frutos (referência) da validade Reiko se caracterizaram pelo menor valor de luminosidade $\quad(L=$ $=22,0)$, e os da variedade IAC-Princesa Isabel pelo maior va lor $(L=32,5)$, ou seja, apresentaram uma cor mais clara em relação às demais variedades, o que concorda com os resultados da avaliação sensorial (Tabela 3). Quando ao líquido exsudado (referência), a variedade IAC-Princesa Isabel apresen tou maior valor $(\mathrm{L}=57,5)$ de luminosidade e a variedade Chan dler o menor $(L=41,5)$, ou seja, o líquido exsudado de tom mais claro é o da variedade IAC-Princesa Isabel e o mais escuro é o da Chandler. Assim sendo, houve maior perda de pigmentos da parte sólida para o líquido exsudado na variedade Chandler, o que também pode ser verificado, observando-se os valores de vermelho (a) e amarelo (b) do liquido exsudado das quatro variedades de morango em estudo (Figura 6). No que diz respeito aos valores de vermelho (a) e amarelo (b) dos frutos (referência) e do líquido exsudado (referência), veri fica-se que as variedades Chandler, Reiko e Sequóia apresentaram valores próximos e a IAC-Princesa Isabel apresentou va lores mais baixos em relação às demais variedades. Assim pode-se dizer que os resultados da avaliação objetiva da cor 


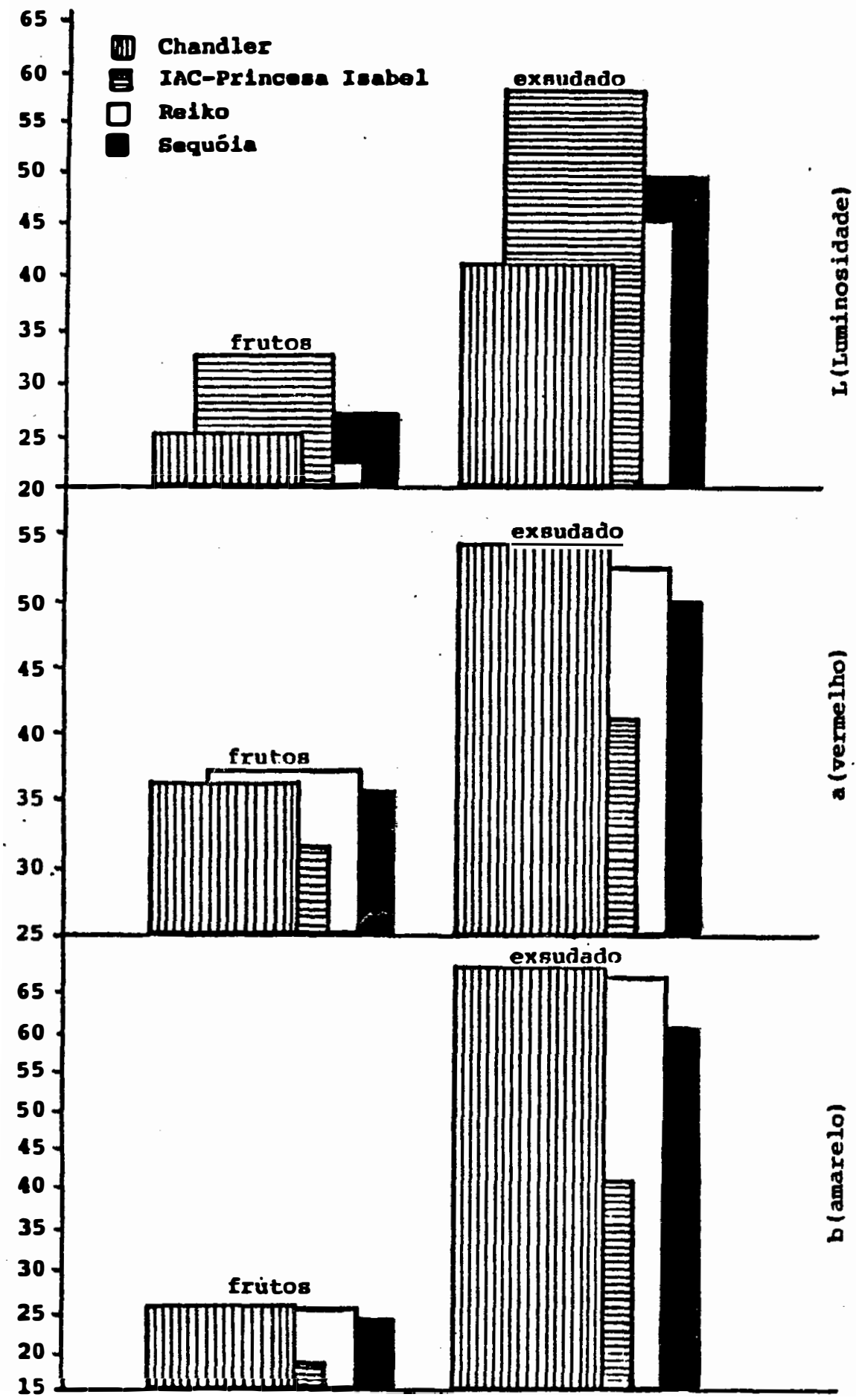

FIGURA 6. Avaliacāo objetiva da $\operatorname{cor}(I, a, b)$ da parte sólida e do liquido exsudado dos morangos congelados, sem tratamento - referência. 
dos frutos e liquido exsudado das amostras denominadas de re ferência seguiram a mesma tendência.

Uma análise geral da cor, por meio da diferen ça total de cor (E) das amostras submetidas aos diferentes tratamentos de pré-congelamento $(1,2,3,4,5$ e 6) em relação às amostras sem tratamento (referência), mostrou pela Ei. gura 7 que para a variedade Chandler, o tratamento 1 (morango + sacarosel foi o que causou menores alterações na cor dos frutos, seguido pelos tratamentos 5 e 6 . Para a variedade IAC-Princesa Isabel, o tratamento 5 foi o que causou menor alteração na cor dos frutos, seguido pelo tratamento 4. Na variedade Reiko, o tratamento 1 causou a menor variação de cor da amostra em relação à amostra referência, seguido dos tratamentos 2 e 4, que causaram alterações totais de cores semelhantes. Para a variedade Sequóia o tratamento 1 foi o que causou menor alteração total de cor dos frutos, seguido do tratamento 4 .

Comparando-se os resultados da avaliação obję tiva da cor com os obtidos pela análise sensorial, pode-se verificar para a variedade Chandler (Tabela 18) que no trata mento 1 não ocorr u perda de coloração, coincidindo com a avaliação, o que não ocorreu com os tratamentos 5 e 6 , onde de acordo com a análise sensorial houve grandes perdas de co loração dos frutos, o mesmo acontecendo com a variedade IAC-Princesa Isabel (Tabela 15). No caso da variedade Reiko, hou ve concordância de resultados (Tabela 17), sendo que o trata mento 1 foi o que causou menores perdas na coloração dos fru 


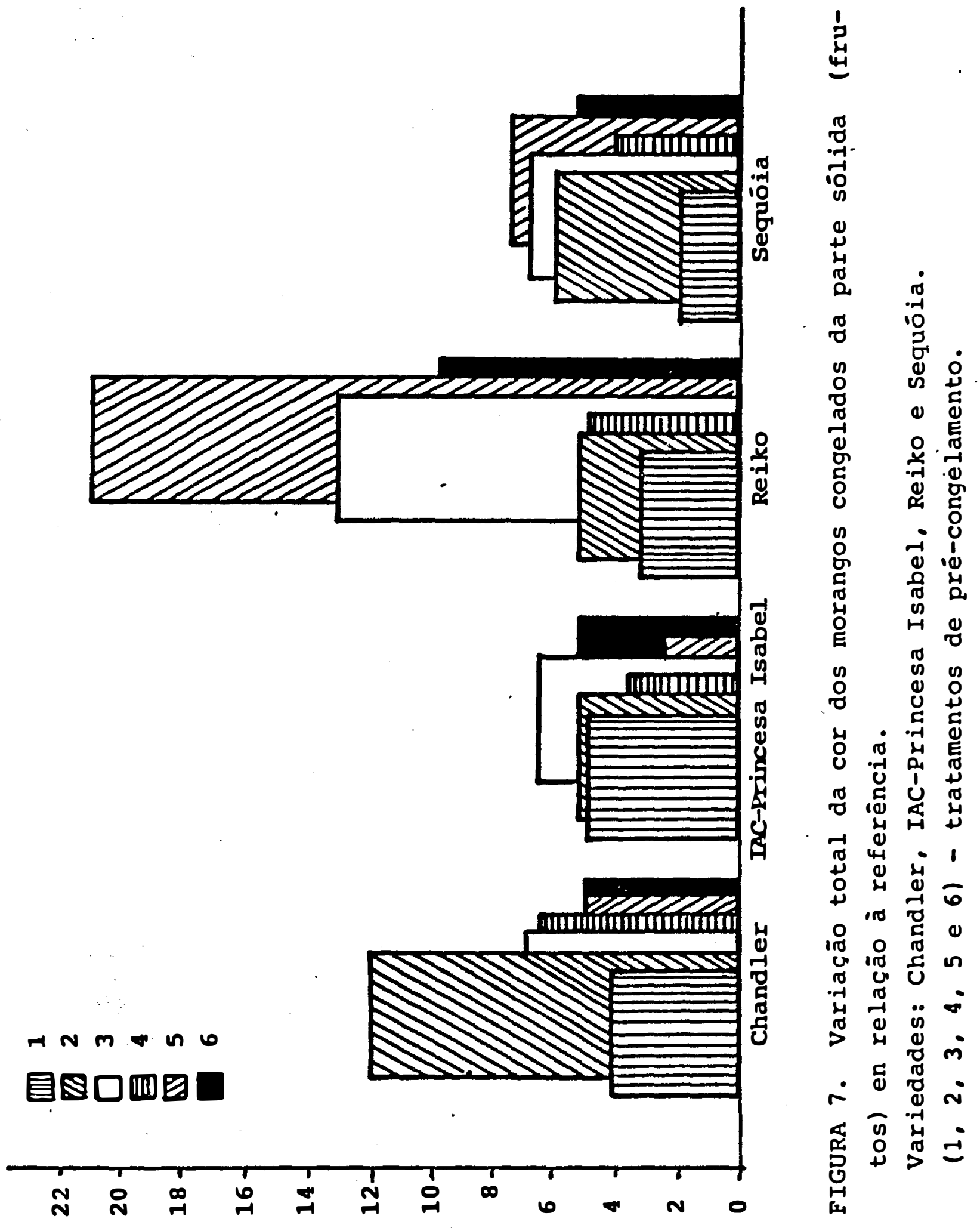


tos, tanto do ponto de vista sensorial como da avaliação objetiva da cor. O mesmo ocorreu com a variedade Sequóia.

Quanto à cor do líquido exsudado das amostras dos seis tratamentos de pré-congelamento das variedades de morango estudadas, verificou-se através da diferença total de cor E (Figura 8) que para a variedade Chandler o tratamento 3 foi o que promoveu a menor diferença de cor entre o líquido exsudado da amostra-referência e dos morangos congelados. Para as demais variedades o tratamento que apresentou menor variação total de cor foi o 6 (Figura 8 ).

\subsubsection{Análises químicas}

Nas Tabelas de 7 a 14 são apresentados os resultados da avaliação objetiva do $\mathrm{pH}$, acidez total titulável, sólidos solúveis e vitamina $C$ do produto processado, que se constituiu em duas partes: parte sólida ou fruto propriamente dito e a parte líquida ou líquido exsudado.

Para as quatro variedades em estudo, os resul tados das análises químicas indicaram que para $\circ \mathrm{pH}$ e para acidez total titulável (ATT) não houve diferença estatística significativa (Tabelas 7, 8, 9 e 10) entre as amostras dos frutos e do líquido exsudado, como também entre as diferentes épocas de avaliação durante o periodo de armazenamento congelado $(450,900,1350$ e 1809 dia).

Comparando-se os resultados obtidos para $\circ \mathrm{pH}$ e para a ATT da matéria-prima (Tabela 2) com os resultados 


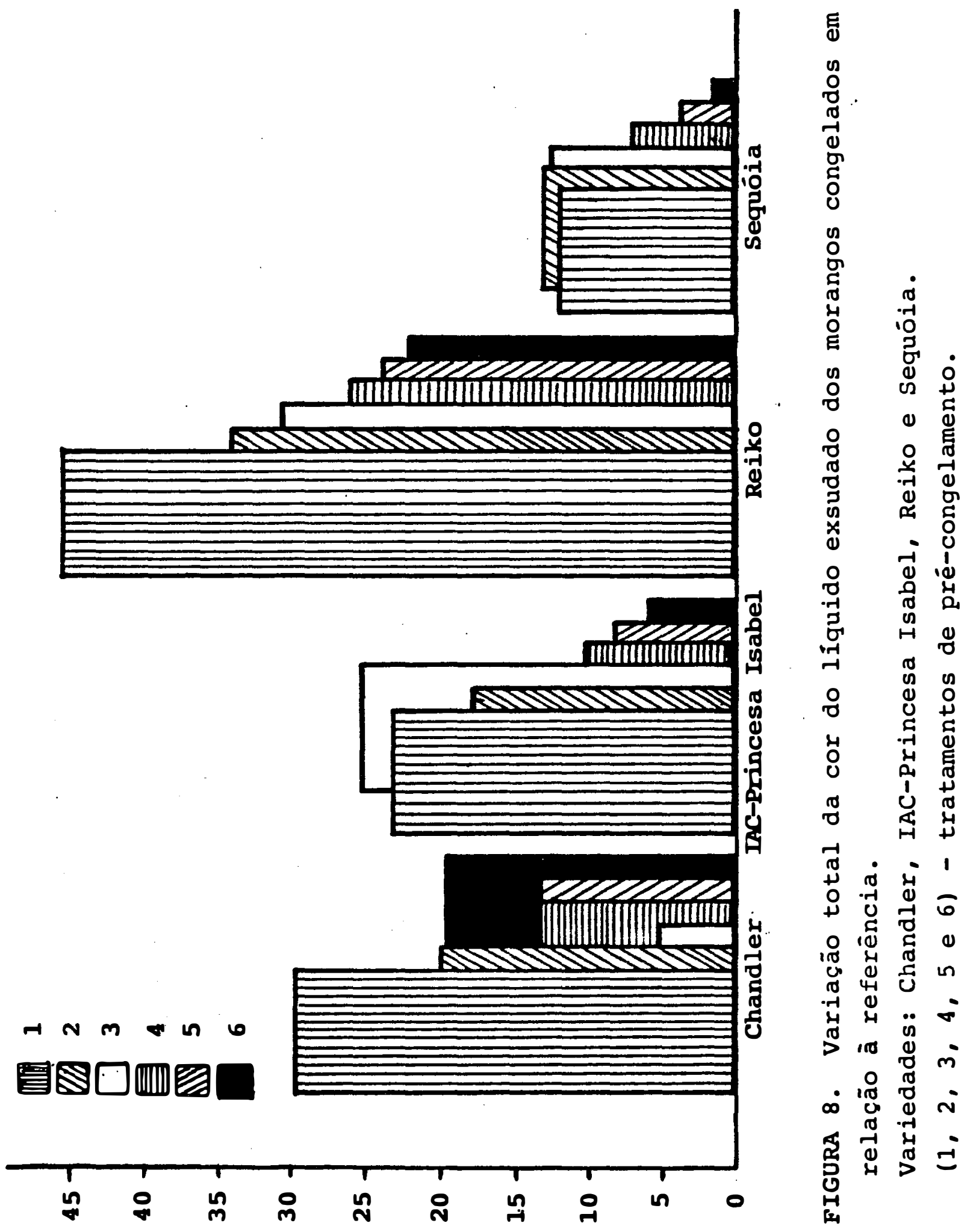




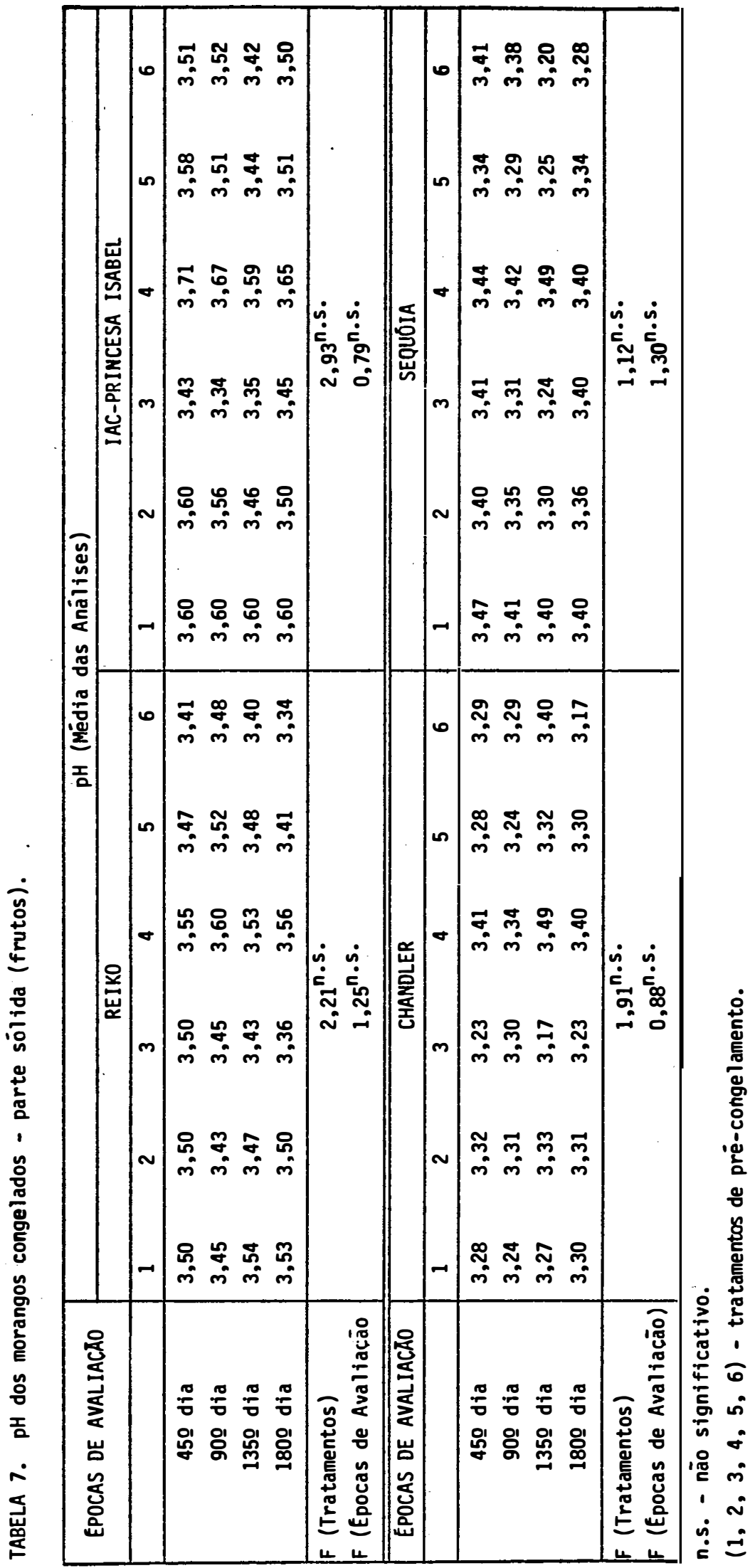




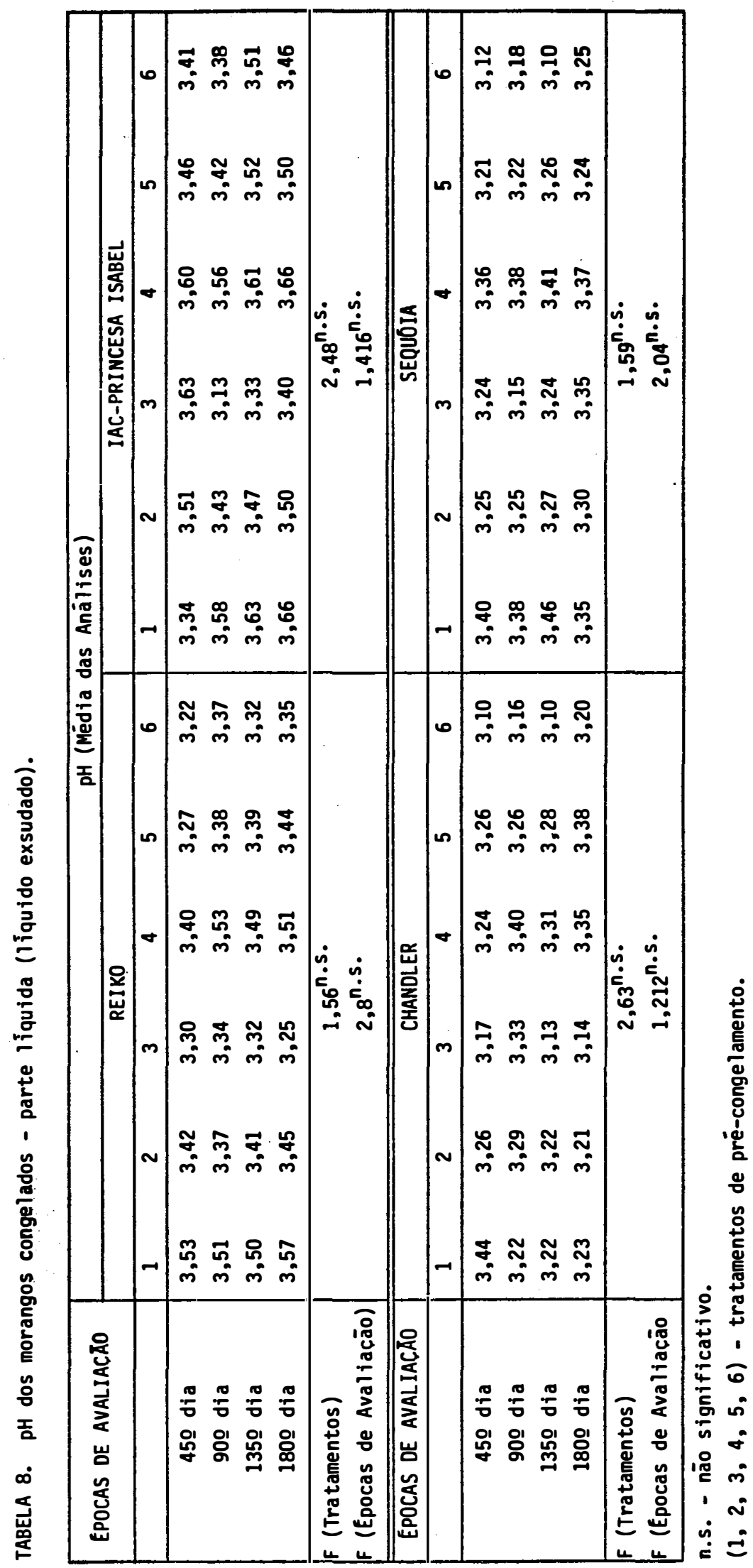




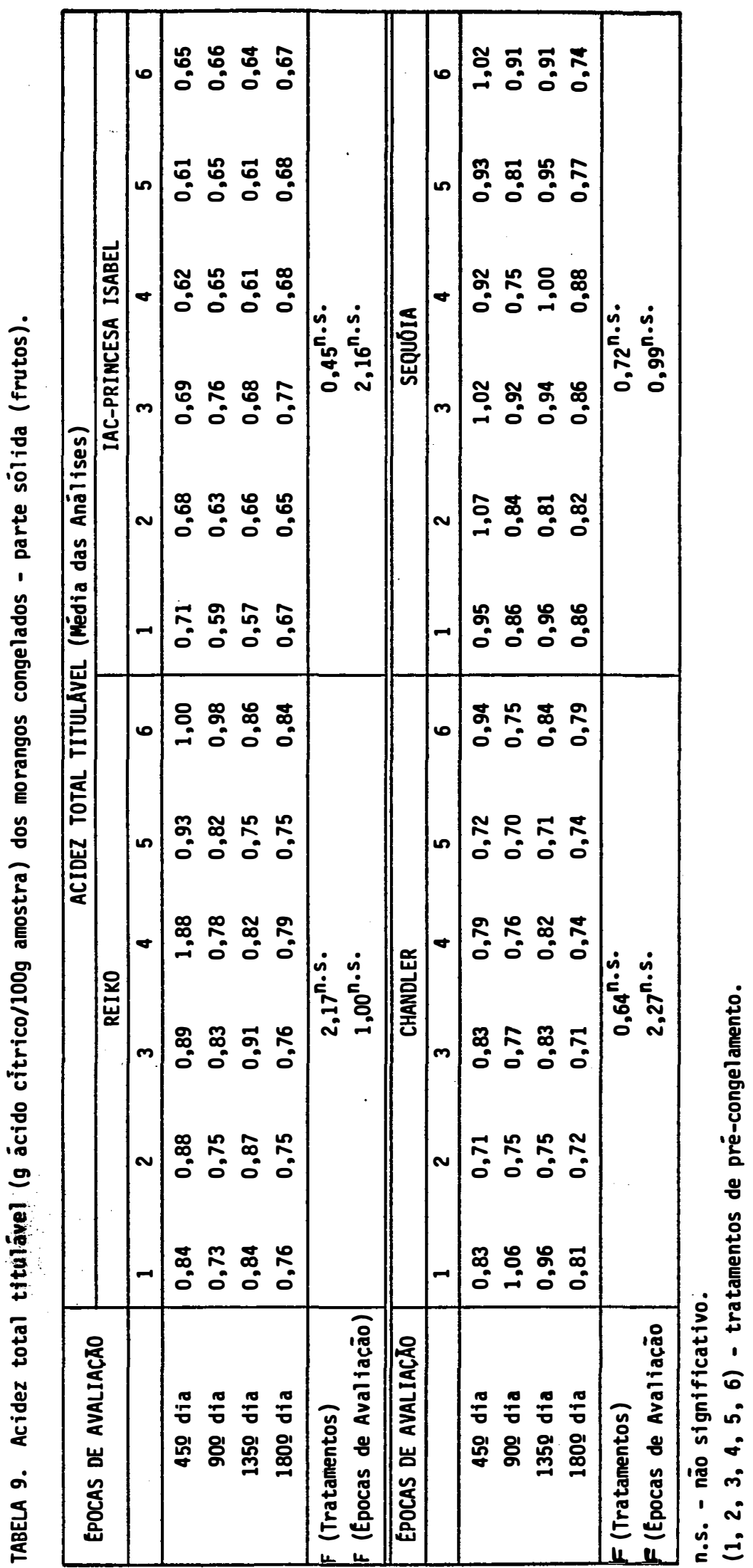




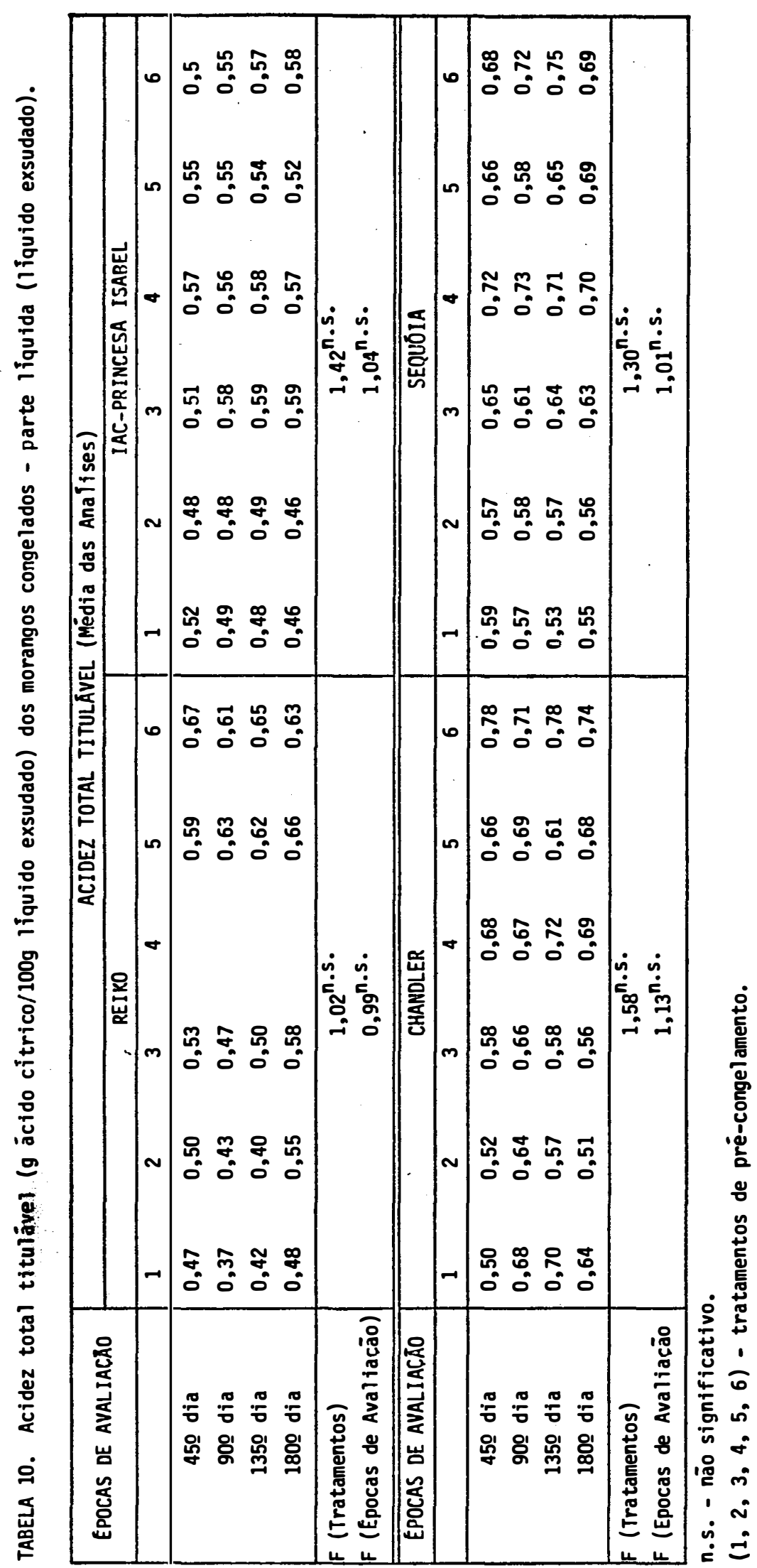


do produto final, verifica-se que os valores mantiveram-se praticamente estáveis durante todo o periodo de armazenamento congelado.

Quanto ao teor de sólidos solúveis (Tabela 11), os resultados obtidos indicaram que houve diferença significativa entre os tratamentos de pré-congelamento para as amos tras da parte sólida, das variedades IAC-Princesa Isabel, Se quóia e Reiko. Para estas três variedades, pode-se verificar que os tratamentos 1,2 e 3, que não utilizaram calor, diferiram dos tratamentos 4,5 e 6, que utilizaram calor. Esta diferença entre os tratamentos ocorreu porque a aplicação do calor, propiciando uma maior troca osmótica entre a sacarose adicionada e os frutos, ocasionou em conseqüência uma elevação do teor de sólidos solúveis da parte sólida (fruto) do produto final.

Para a variedade Chandler, apesar de também ter ocorrido uma elevação do teor de sólidos solúveis nas amostras tratadas com calor (tratamentos 4,5 e 6), as diferenças entre os tratamentos não foram estatisticamente signi ficativas. Os frutos da variedade Chandler tendo uma textura bem mais resistente (Tabela 2 ) não permitiram que ocorresse uma troca osmótica tão intensa com a sacarose, como aconteceu com as outras variedades.

Quanto ao teor de sólidos solúveis da parte liquida, a Tabela 12 mostra que apenas para as variedades Rei ko e Sequóia houve diferença significativa entre os tratamen tos que utilizaram calor $(4,5$ e 6$)$ e os que não utilizaram 


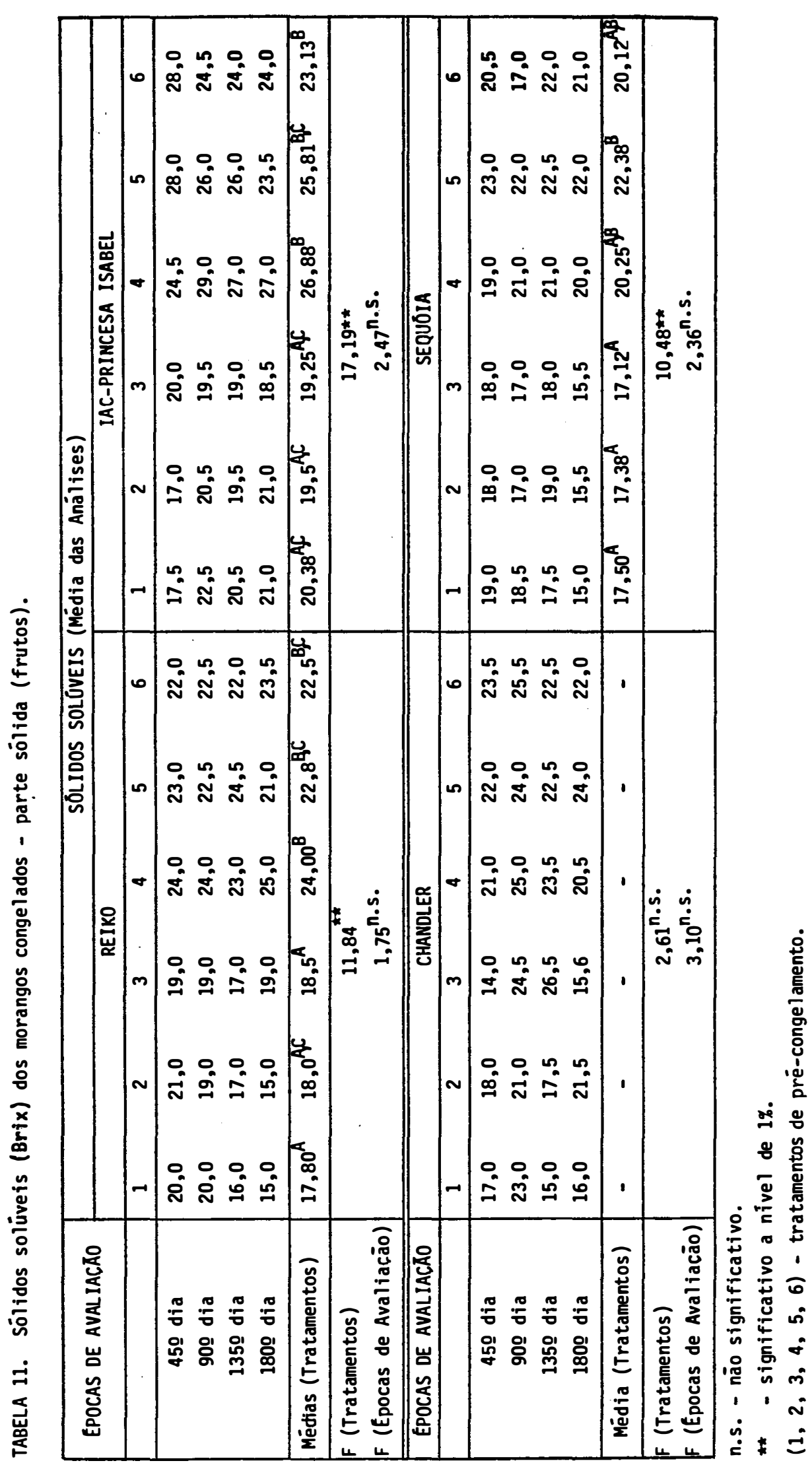




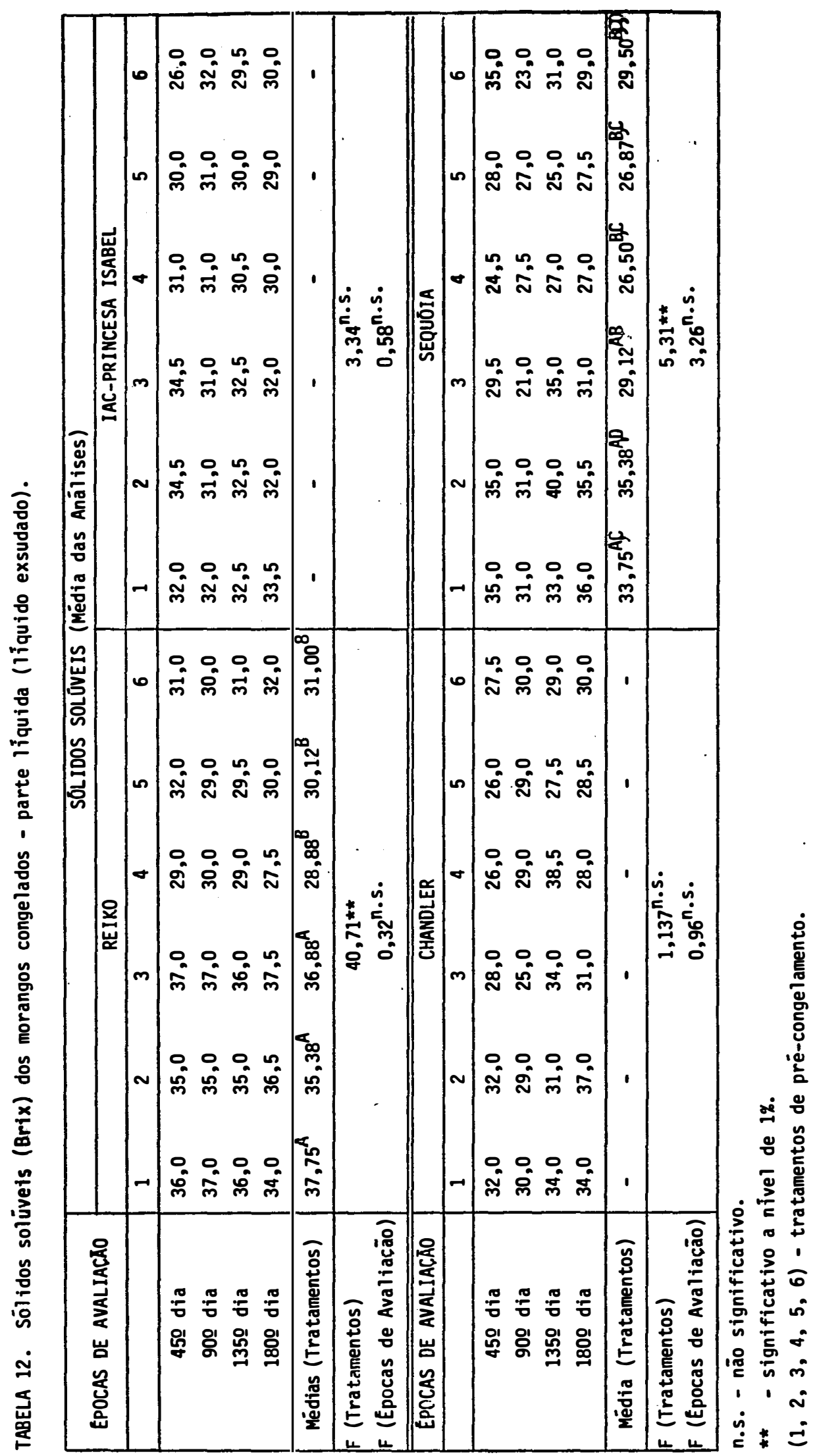


calor (1, 2 e 3). Isto indica que para estas duas variedades a aplicação de calor propiciou uma maior troca osmótica entre a sacarose adicionada e os frutos, diminuindo o teor de sólidos solúveis do líquido exsudado daquelas amostras-(tratamentos 4,5 e 6 ).

Pelas Tabelas 11 e 12 também pode-se observar que o período de armazenamento congelado não afetou 0 teor de sólidos solúveis, tanto da parte sólida (frutos) como da parte líquida (líquido exsudado), para as quatro variedades estudadas (não houve diferença estatística significativa entre épocas de avaliaçãol.

Os teores de vitamina $C$ no produto final, em ambas as partes, sólida e líquida (Tabelas 13 e 14), foram inferiores aos encontrados nos frutos "in natura" (Tabela 1), notadamente nos tratamentos 4,5 e 6 (parte sólida), em que os frutos sofreram aquecimento, indicando que o calor pode ter acelerado a oxidação da vitamina C. Outra possivel explicação seria a maior exsudação que ocorreu com a aplicação do calor, arrastando-se assim maior quantidade da vitamina hidrossolúvel para o líquido exsudado. Esta parece ser a explicação mais viável, pois como mostra a Tabela 14, o maior teor de vitamina $C$ encontra-se no líquido exsudado resultante dos tratamentos $(4,5$ e 6$)$ que sofreram a ação do calor.

A Tabela 13 (parte sólida) mostra que existe diferença significativa entre os tratamentos de pré-congelamento para todas as variedades estudadas, com exceção da Se- 
quóia. Quanto ao teor de vitamina C da parte liquida (Tabela 14) os tratamentos apresentaram diferença estatistica significativa para as quatro variedades estudadas.

As Tabelas 13 e 14 também mostram que houve diferença estatistica significativa entre as épocas de avaliação, indicando que durante o armazenamento congelado ocor reram perdas no teor de vitamina $C$ para as quatro variedades: IAC-Princesa Isabel - 208; Sequóia - 678; Reiko - 198; e Chandler - 41,58. Comparando-se estes resultados com os obtidos por KOROBKINA et al. (1975) conclui-se que a vitamina C apresentou maior estabilidade no presente estudo. Já em rela ção aos valores encontrados em pesquisa realizadas por DERBE DEVA \& KROTOV (1972) e por FIK \& MACURA (1986), a vitamina C foi menos estável nas variedades em estudo. Embora tenham ocorrido perdas, as quatro variedades apresentaram, ao final de 180 dias de armazenamento, consideráveis teores de vitami na C (Tabelas 13 e 14$)$. 


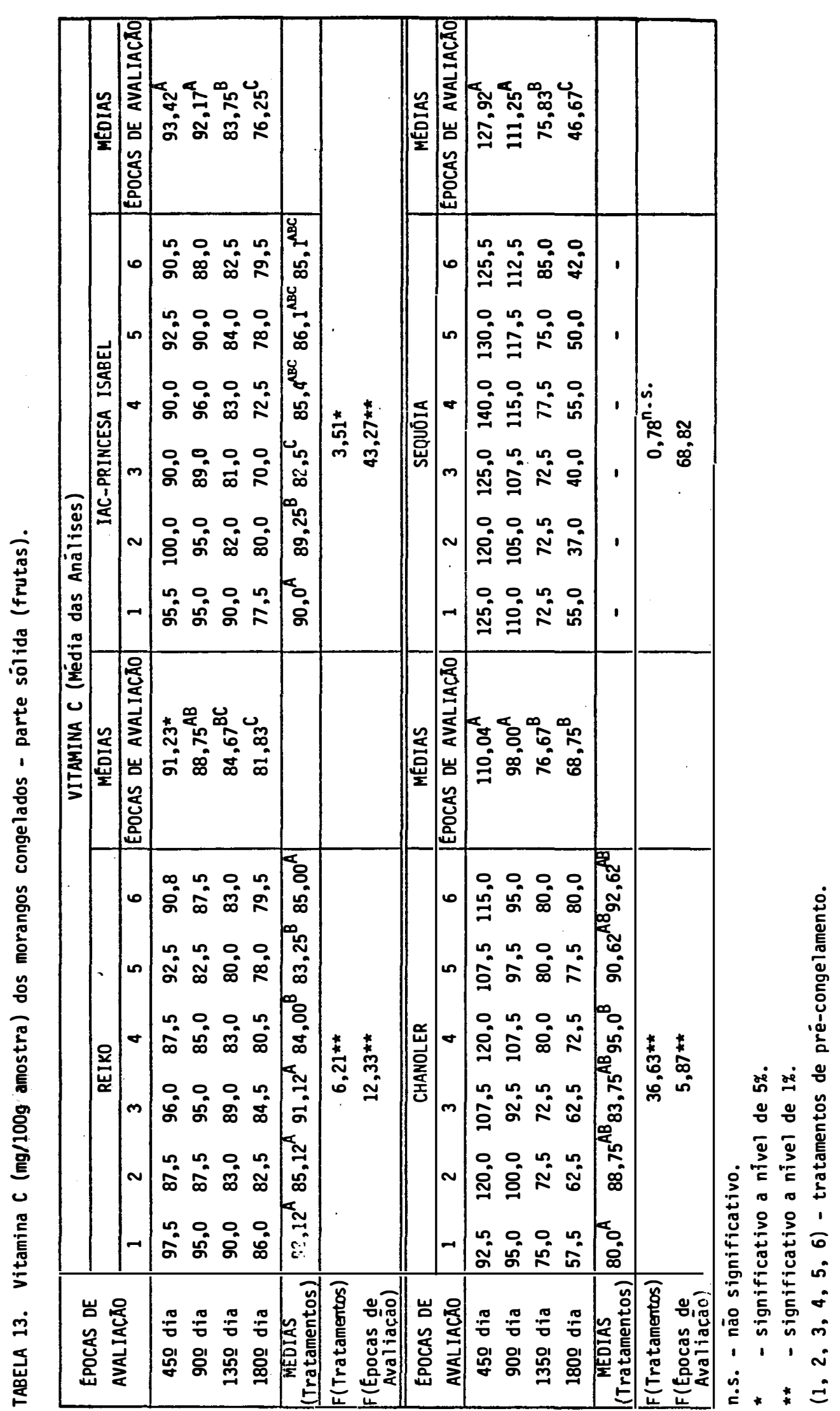




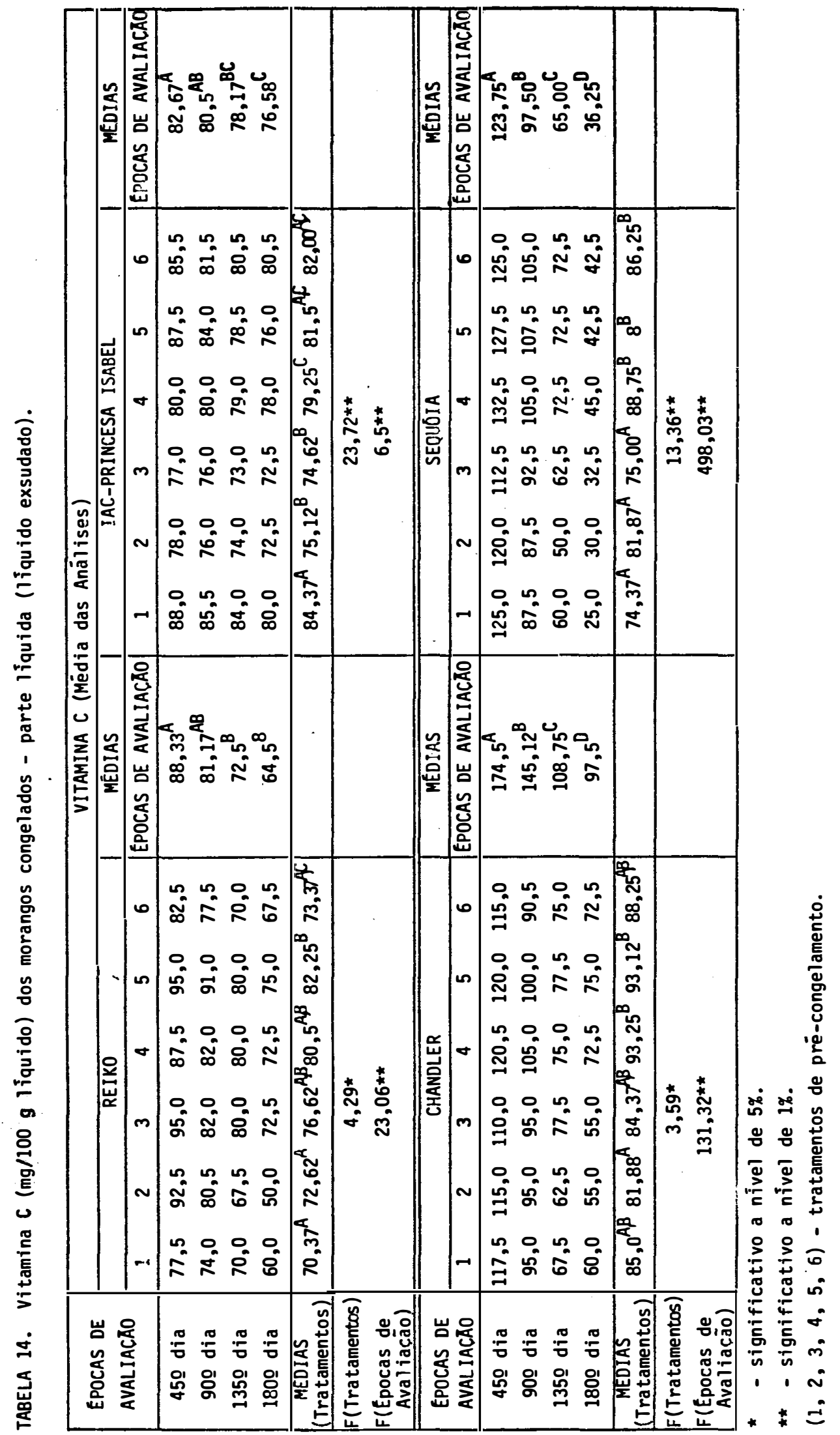




\subsubsection{Análises sensoriais}

As Tabelas $15,16,17$ e 18 apresentam os resultados da avaliação subjetiva do sabor, textura e cor dos morangos congelados.

Os frutos obtidos mostram que os tratamentos de pré-congelamento não influenciaram o sabor das quatro variedades de morango em estudo. De forma geral, o produto pro cessado recebeu notas que correspondiam ao termo "sabor mode rado" na escala utilizada na avaliação sensorial (Figura 2).

No que diz respeito à estabilidade ao armazenamento congelado, apenas o sabor da variedade sequóia mante ve-se estável, conforme pode ser verificado na Tabela 16, pois não houve diferença significativa entre as diferentes épocas de avaliação $(450,900,1350$ e 1800 dia de armazenamento con gelado). Com as variedades Reiko, Chandler e IAC-Princesa Isa bel, ocorreram mudanças mais acentuadas de sabor durante o periodo de armazenamento (Tabelas 15, 16 e 18).

A interação Tratamento x Epocas de Avaliação mostrou que o sabor das variedades Reiko e IAC-Princesa Isabel diminuiu com o decorrer do periodo de armazenamento e de forma mais intensa para os tratamentos 4, 5 e 6 (Tabelas 15 e 17)

A textura das variedades Sequóia, Reiko e Chan dler (Tabelas 16, 17 e 18) foi influenciada pelos tratamentos de pré-congelamento, sendo que as amostras dos tratamentos 1, 2 e 3 apresentaram maior firmeza que amostras dos tra 
tamentos 4, 5 e 6. Assim, pode-se dizer que, do ponto de vis ta sensorial, a aplicação de calor que foi utilizada nos tra tamentos 4, 5 e 6 provocou perda de textura do produto. Quan to à variedade IAC-Princesa Isabel os tratamentos de pré-con gelamento não alteraram a textura da mesma, que apresentou desde a matéria-prima os menores valores de textura entre as quatro variedades de morango em estudo (Tabelas 1 e 15).

A estabilidade do armazenamento, no caso da textura, foi verificada para a variedade Chandler, que se man teve firme durante os 6 meses de armazenamento congelado (Ta bela 18).

As demais variedades: Reiko, IAC-Princesa Isa bel e Sequóia tiveram a textura diminuida durante $\circ$ periodo de armazenamento congelado (Tabelas 15, 16 e 17).

Através da interação Tratamento $x$ Épocas de Avaliação, verifica-se que a textura das variedades Reiko e Chandler foi afetada, particularmente para os tratamentos 4, 5 e 6 , sendo a perda de textura, nestes casos, muito mais pro nunciada que no caso dos tratamentos 1,2 e 3 (Tabelas 17 e $18)$.

A cor dos frutos foi o atributo mais afetado pela ação do calor nos casos dos tratamentos 4,5 e 6, assim como pela ação do tempo durante o periodo de armazenamento e da interação Tratamento x Épocas de Avaliação. De acrodo com as médias obtidas para este atributo, pode-se verificar que todas as variedades em estudo, submetidas aos tratamentos 4, 
5 e 6 receberam notas que correspondem à "cor fraca", ou seja, a aparência dos frutos foi afetadas pela perda de cor dos mesmos (Tabelas 15, 16, 17 e 18).

Comparando-se os resultados da análise sensorial dos morangos "in natura" (Tabela 3 ), com os resultados obtidos na análise do produto final, pode-se verificar que, para as variedades Reiko e Chandler (Tabelas 17 e 18), o con gelamento provocou perda de sabor, que passou de "intenso" para "moderado". As variedades Sequóia e IAC-Princesa Isabel apresentaram-se estáveis ao congelamento em termos de sabor. No caso da cor e da textura, todas as variedades em estudo foram afetadas do ponto de vista sensorial, mas a ordem de coloração e de firmeza iniciais foram mantidas, ou seja, a variedade Chandler foi considerada a mais firme e a mais colorida, tanto quanto "in natura" como no produto final-fruto congelado (Tabelas 3 e 18). 


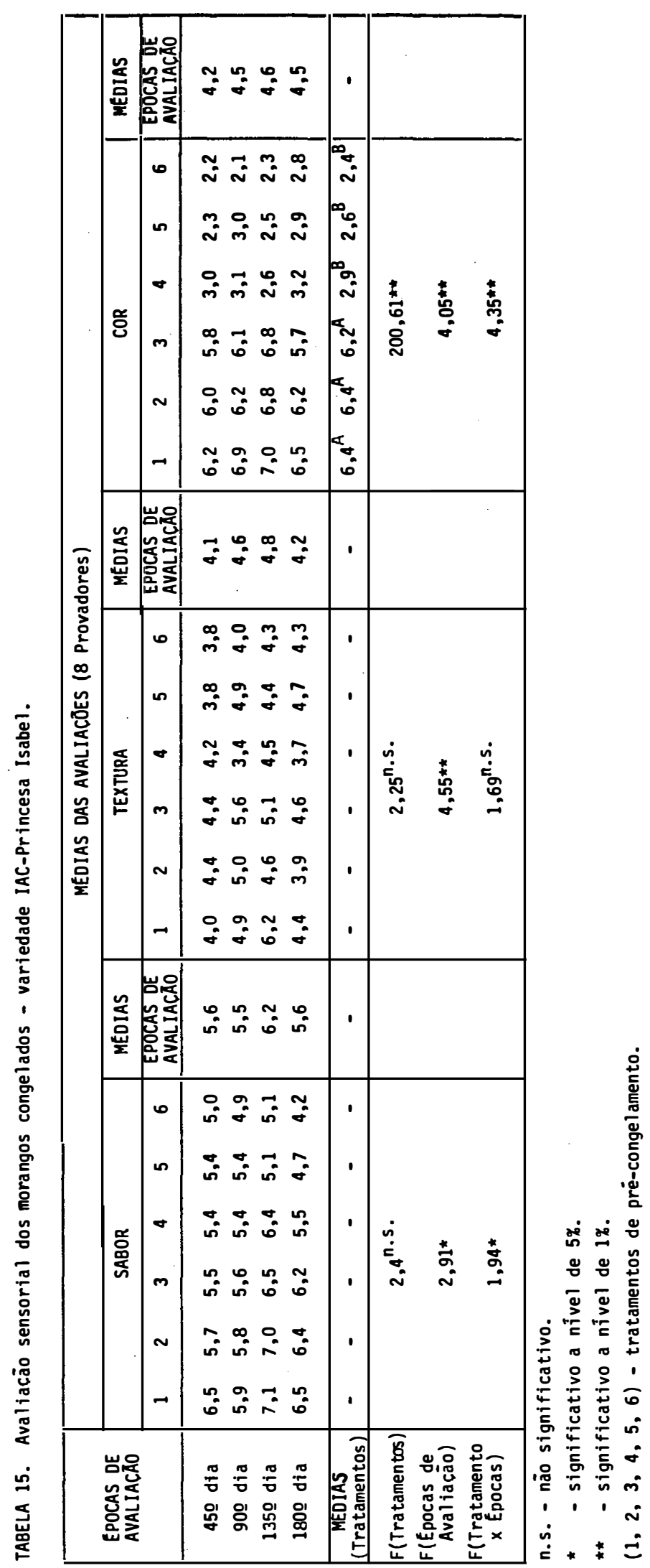




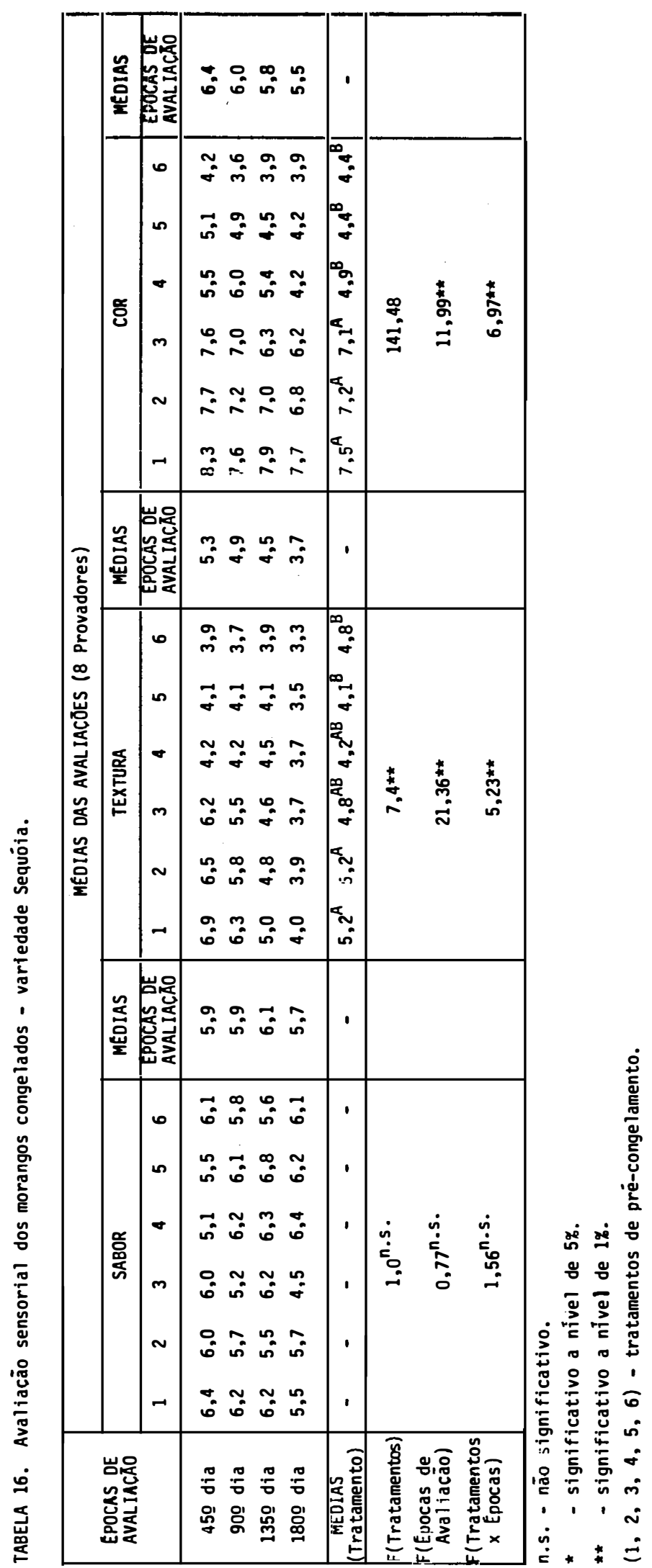




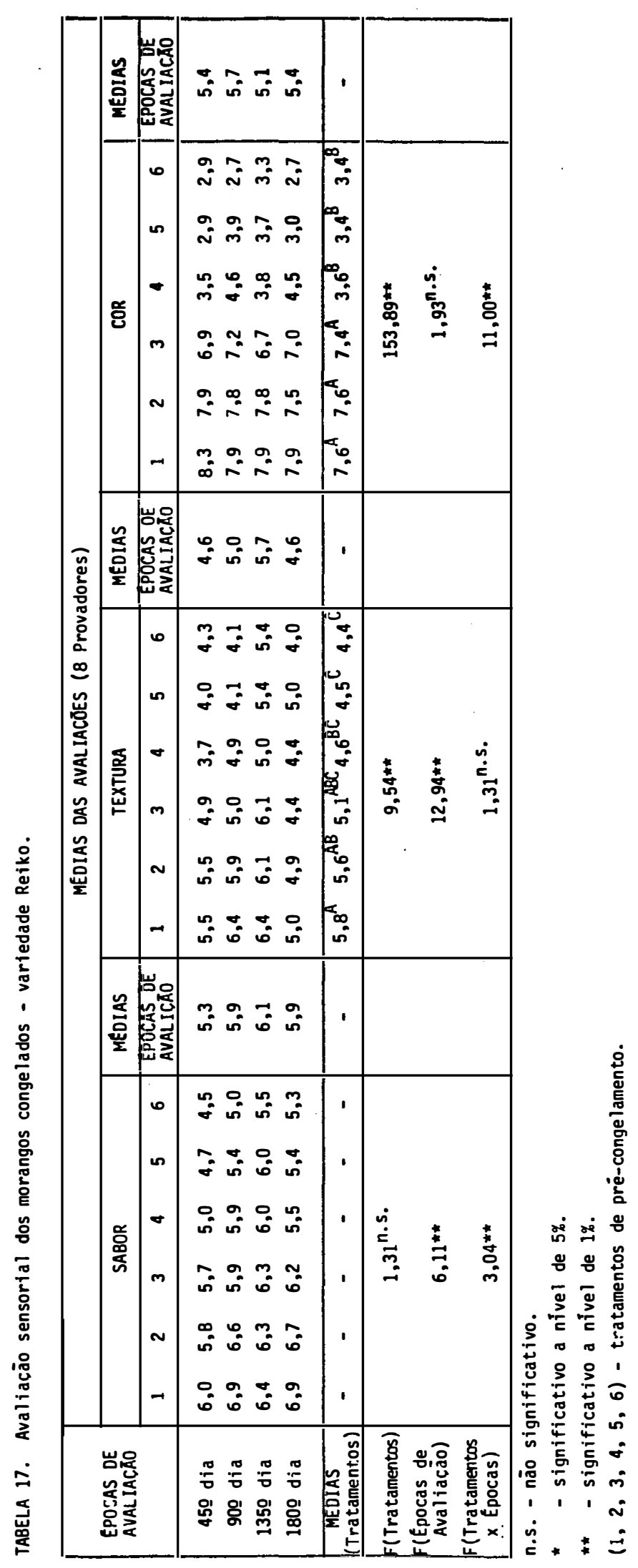




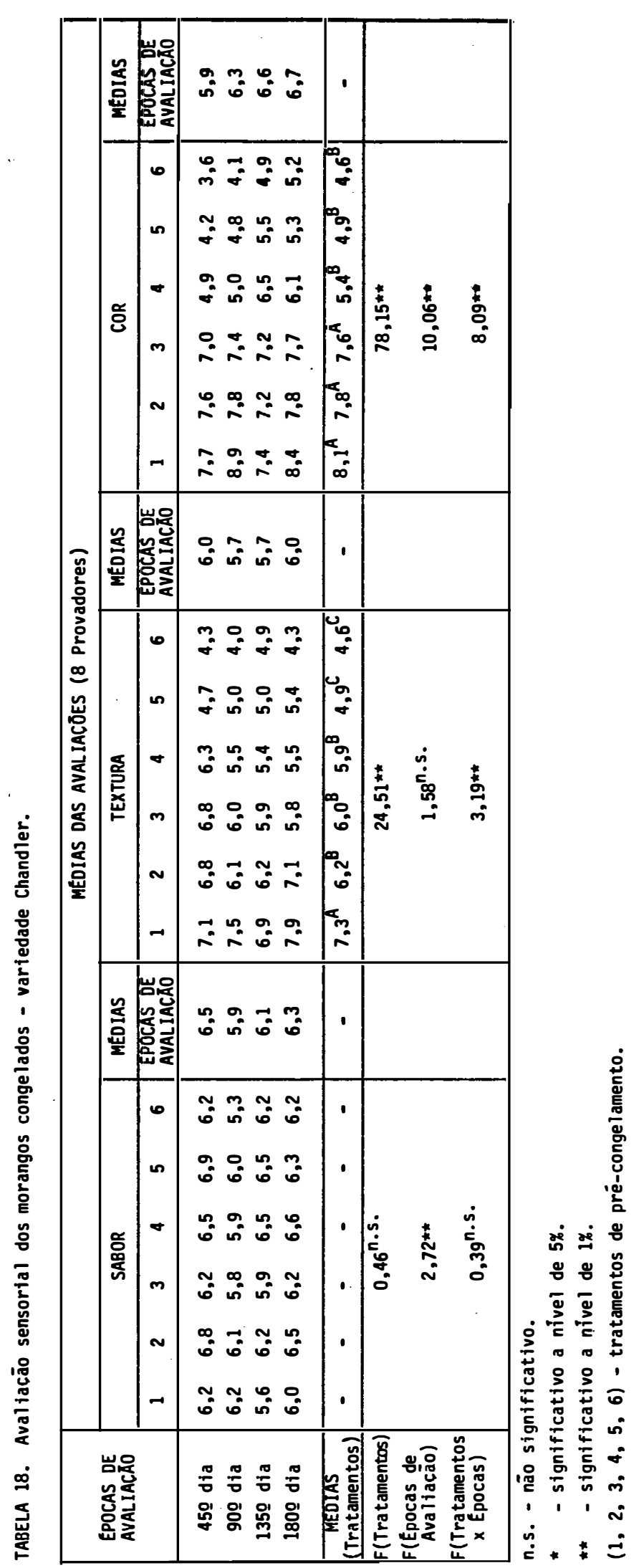




\section{CONCLUSÕES}

Com base nos resultados obtidos, as seguintes conclusões podem ser apresentadas:

- a matéria-prima utilizada no presente estu. do, apresentou ótima qualidade, do ponto de vista físico (tex tura, percentagem de rendimento, suculência), químico (ATT, Brix, $\mathrm{pH}$, teor de vitamina C) e organoléptico (sabor, cor e textura) ;

- a variedade Chandler é a mais firme e a de melhor lcor entre as variedades estudadas;

- a variedade Sequóia apresentou o teor de vitamina $C$ mais elevado entre as variedades estudadas;

- a variedade Reiko é a mais doce e a de melhor sabor entre as variedades estudadas;

- os tratamentos de pré-congelamento, notada mente os que utilizaram aplicação de calor afetaram o teor de vitamina $C$ dos frutos, ou seja, ocorreu diminuição deste 
no periodo de armazenamento congelado (180 dias). Esta diminuição foi acelerada pela aplicação de calor;

- a variedade que apresentou maiores niveis de vitamina $C$, ao final dos 180 dias de armazenamento congelado, foi a Reiko:

- no que diz respeito à textura dos frutos, os aditivos utilizados nos tratamentos de pré-congelamento, pectina e cálcio, tiveram efeito positivo sobre a textura dos frutos das variedades Reiko, Sequóia e IAC-Princesa Isabel. A variedade Chandler se destacou como sendo sensivelmente me lhor que as demais, independentemente dos tratamentos aplica dos;

- em termos de cor, a variedade IAC-Princesa Isabel se apresentou mais clara que as demais e a Chandler como a mais escura, ou seja, a mais vermelha, o que é de gran de importância no caso dos morangos;

- o calor promove a passagem de grande quantidade do conteúdo de pigmento dos frutos (parte sólida) para o líquido exsudado;

- o tratamento de pré-congelamento, que utilizou cálcio, pectina e sacarose (sem aplicação de calor), mostrou-se eficiente para todas as variedades em estudo, di- 
minuindo a perda de líquido por exsudação, quando em compara cão com os demais tratamentos utilizados;

- quanto aos atributos sensoriais, o sabor dos frutos não foi afetado pelos tratamentos de pré-congelamento, permanecendo estável durante os 180 dias de armazenamento;

- a textura dos frutos foi afetada pelos tra tamentos de pré-congelamento, exceto no caso da variedade IAC-P: incesa Isabel. Os menores valores foram obtidos pelos tratamentos que utilizavam calor;

- o calor também foi prejudicial para a cor do produto, ou seja, com o aquecimento houve maior exsudação de liquido e maior passagem do pigmento (antocianina) do fru to (parte sólida) para o líquido exsudado, descolorindo os frutos.

Finalmente, em termos de adequabilidade ao congelamento, a melhor variedade foi a Chandler, seguindo-se as variedades Reiko, Sequóia e IAC-Princesa Isabel, em ordem decrescente de atributos apropriados. 


\section{REFERÊNCIAS BIBLIOGRÃFI CAS}

AOAC. Association of Official Agriculturalchemists - Official Methods of Analysis. $12^{\text {th }}$ ed., Washington, DC, 1975, 1094p.

BERNHARDT, L.W.; TOCCHINI, R.P.\& PASCHOALINO, J.E. Mudanças que ocorrem durante o armazenamento de frutas e hortaliças congeladas. Boletim do Instituto de Tecnologia de Alimentos, Campinas, $16(1): 9-34,1979$.

BOURNE, M.C. Effect of Temperature on Firmness of Raw Fruits and Vegetables. Journal of Food Science, Chicago, 47:440-444, 1982

BRINGHURST, R.S. \& VOTH, V. Sequóia... University of California Centennial. Strawberry Variety. Califronia Agriculture, Davis, May, 1968

CHARLAMOWICZ, Z.; SKRET, B. \& SOBIECH, W. Changes in anthocyanin pigments in processed strawberries. Prace Instytulow i Laboratoriow Badawczych Przemyslo Spozywczego. 21 (1): 251-263, 1971. (FSTA, Abstract, 6J1019, 1972). 
CRIVELLI, G. \& ROSATI, P. Reserch on quick freeezing of strawberry. VII. Influence of pre-freezing treatment on berry quality. Annali-dell Instituto - Sperimentale - per - la Valorizzazione - Tecnologia - dei - Prodotti - Agricoli, Roma; 4: $73-78,1973$.

DAWSON, R.H. Sensory texting guide for panel evaluation of food and beverages. Food Technology, Chicago, 18(8):25-31, 1964 .

DELGADO, A.E.; RUBIOLO, C.A. \& GRIBAUDO, L.M. Characteristic Temperature Determination for Strawberry Freezing and Thawing. Journal of Food Processing, Westport, 14:231-240, 1990 .

DERBEDEVA, E.A. \& KROTOV, E.C. Vitamin C losses in strawberries and blanckeurrants duraning freezing and cold storage. Kholudil'naya Tekhnika, (8):42-43, 1972. (FSTA, Abstract, 7J968, 1973).

FERHRMANN, H. DIAMOND, A.E. Peroxidase activity and Phyto pora resistence in different organs of the potato plant. Phytopatology, Lancaster, 57:69-72, 1967.

FIK, M. \& MACURA, R. Changes of quality of frozen fruits kept in cold storage. Chlodnictwo, 21:8, 13-15, 1986. (Nutri tion-Abstracts and Reviews -. Series A, 058 02626, 1988). 
FUSTER, C.: PRESTAMO, G. \& CANET, W. Effect of Pre-treatments and Freezing of Different Strawberry Varieties. Refrigeration Science and Technology, p. 350-356, 1982.

FUSTER, C.: PRESTAMO, G. \& ESPINOSA, J. Influence of treatments prior to freezing on the quality and stability of fruits and vegetables during frozen storage. In: SIMPOSIUM THERMAL PROCESSING AND QUALITY OF FOODS. Madrid, Espanha, European Cooperation in Scientific \& Technical Research, 1984, p. 671-677.

GARROTE, R.L. \& BERTONE, R. Chemical evaluation and the suitability for freezing of strawberry varieties. Revista del Instituto de Tecnologia de Alimentos, I. T. A. Santa Fe, 1: $81-99,1975$.

GIRARDOT, N.F.; PERYAM, D.R. \& SHAPIRO, L. Selection of sensory testing panels. Food Technology, Chicago, $6(4)$ : $140-143,1952$

GUEGOV, Y.; KAROV, T.; KALINOV, V.; NIKOLOV, D. Freezing Suitability of Some strawberry Varieties. In: Progress in the design and operation of refrigeration equipement and in the processing of fruit and vegetables by refrigeration. Refrigeration Science and Technology, 4, Paris, 1982. Conference proceedings, Paris, França, International Institute of Refrigeration, p. $233-238$. 
HUDSON, M.A.; LEACH, M.; SHARPLES, J.V. \& PICKFORD, E. Home Frozen Strawberries. I. Influences of medium, fanning, syrup temperature, soaking time, storage time and temperature, and rates of freezing and thawing on sensory assessment. Journal of Food Technology, Oxford, 10 (6):681-788, 1975a.

HUDSON, M.A.; HOLGATE, M.E.; GREGORY, M.E. \& PICKFORD, E. Home Frozen Strawberries. II. Influence of additives en syrup on sensory assessments and texture measurements. Journal of Food Technology, Oxford, 10 (6):689-698, 1975b.

HUDSON, M.A.; RICKETTS, V.A. \& HOLGATE, M. Home frozen strawberries. III. Factors affecting sensory assessment. Journal of Food Technology, Oxford, 12(4):421-426, 1977.

INSTITUTO AGRONOMICO DE CAMPINAS. IAC-Princesa Isabel. Sele ção promissora de morangueiro. O Agronômico, Campinas, $\underline{41}$ (3) : 268, setc./dez., 1989 .

KOROBKINA, Z.V.; ABDONOVA, M.K.H. \& KOSENKO, M.Ya. The stability of ascorbic acid in frozen fruit. Konservanaya $i$ Ovosshchesuhil'naya Promyshlennost. N. 2,25-26, 1975. (FSTA, Abstract, 7J1020, 1976).

KOROBKINA, Z.V.; DANILENKO, G.V.; DRUZHINSKAYA, L.P. \& MANDRIKA, B. I. Effect of preliminary treatment of ran materials on retention of vitamins in frozen fruit and vegetables. Konservanaya i Ovoshchesushit'naya Promyshlennost. N. 5,36-39, 1978. (FSTA, Abstract, 7J1266, 1979). 
LISBAO, R.S. Diagnōstico e programa de pesquisa de hortaliça. Campí nas, Instituto Agronômico de Campinas - IAC, 1991. p. 53.

MAIN, G.L.; MORRIS, J.R. \& WEHNT, E.J. Effect of preprocessing treatments on the firmness and quality, characteristics of whole and gliced strawberries after and thermal processing. Journal of Food Science, Chicago, 51(2):391-394, 1986 .

MARTIN, S.L. Selection and training of sensory judgs. Food Technology, Chicago, 27. (11):22-26, 1973.

MORRIS, J.R.; SISTRUNK, W.A.; SIMS, C.A.; MAIN, G.L.\& WEHNT, E.J. Effects of Cultivar, Postharvest Storage, Preprocessing Dip Treatments and Style of Pack on the Processing Quality of Strawberries. Journal American Society, Horticultural Science, Alexandria, $\underline{110(2)}: 172-177,1985$.

NARUKAMA, N.; ISHIABASHI, K.; OGIWARA, S. \& TOKI, T. The Pedigree and characteristics of new strawberry variety "Reiko". Bull Chiba Agric. Exp. Stn., 22:45-55, 1981.

NEVES FILHO, L. de C. Congelamento de morango. In: SIMPOSIO SOBRE A CULTURA DO MORANGUEIRO, 1, Cabreúva, Casa da Agricultura de Cabreúva/DIRA, 20 e 21 de junho, 1986. Jaboticabal, Sociedade de Olericultura do Brasil e FCAVJ/NESP, 1986, p. 65-88. 
PASChOALINO, J..E. et al. "Congelamento de Frutas e Hortalilas". In: TEIXEIRA NETO, R.O., coord. Curso de Alimentos Con gelados, Campinas, ITAL, 1979, p. 2-27.

PASCHOALINO, J.E. "Congelamento de Hortaliças". In: PASCHOALINO, J.E. Processamento de Hortaliças, Campinas, ITAL, 1989 , p. 48-69.

PASCHOALINO, J.E. Fatores que influem sobre a qualidade do morango congelado. Boletim do Instituto de Tecnologia de Alimentos, n.51, mai./jun., 1977.

PASCHOALINO, J.E.; ZUCCHINI, A.G.; BERNHARDT, L.W.; SILVA, S.D. da; FERREIRA, V.L.P. Estudo sobre a avaliação de diferentes variedades locais de morango em relação à sua ade quabilidade para congelamento. Coletânea do Instituto de Tecno logia de Alimentos, Vol. 5, 1973/74.

PASSOS, F.A. Caracterização de clones nacionais e introduzidos de morango (Fragaria xananassa Duch.), visando o uso imediato na horticul-

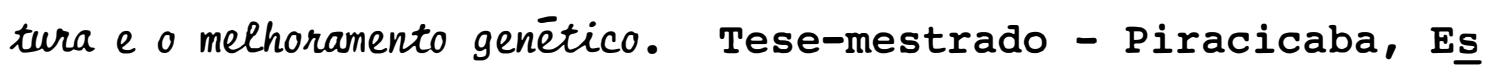
cola Superior de Agricultura "Luiz de Queiroz", da Universidade de São Paulo, 1982. 116p.

PONTING, J.D. \& JOSLYN, M.A. Ascorbic acid oxidation and browing in apple tissue extracts. Archives of Biochemistry, New York, 19:47-63, 1948 .

SAWYER, F.M. Interacion of sensory panel and Instrumental Measurement. Food Technology, Chicago, 25(3):51-52, 1971. 
SELVARAJ, Y.; DIVAKAR, N.G.; SURESH, E.R.; IYER, C.P.A. \& SUBRAMANYAN, M.D. Studies on chemical composition of twenty strawberry (Frangaria ananassa) varieties. Journal of Food Science and Technology, 13, jul./aug., 1976.

SHAU, N.L. changes in the coloring of strawberries and raspberries during freezing and storage. Nauchni Trudove, Vissh Institut po Khranitelna $i$ Ukusoya Promyshlennost, $20(1): 37-50$, 1973a. (FSTA, Abstract, 9J1235, 1974).

SHAU, N.I. Changes in anthocyanin content of strawberries and raspberries during freezing and storage. Nauchni trudove. Vkusova promyshlennost, 20⑴:51-60, 1973b. (FSTA, Abstract, 9J1236, 1974) .

SHERMAN, P. Structure and textural properties of foods. Food Technology, Chicago, p. 69-79, mar., 1979.

SHIROSE, I. Estatistica Aplicada à Experimentação Onganoléptica, Cam pinas, Instituto de Tecnologia de Alimentos, 1985, p. 96-111 .

SISTRUNK, W.A. \& MOORE, J.N. Assessment of Strawberry Quali ty - Fresh and Frozen. Food Technology, Chicago, 21:449-453, 1967 .

SISTRUNK, W.A.; WANG, R.C. \& MORRIS, J.R. Effect of combining mechanically harvested green and ripe puree and sliced fruit, processing methodology and frozen storage on quality of strawberries. Journal of Food Science, Chicago, 48:1609-1612, $1616,1983$. 
SKREDE, G. Changes in Sucrose, Fructose and Glucose Content of Frozen Strawberries With Thawing. Journal of Food Science, Chicago, 48:1094-1096, 1100, 1983.

SZCZESNIAK, A.S.; SMITH, B.J. Observations of strawberry texture a three-pronged approach. Journal of Texture Studies, Dodrecht, $\underline{1}(1): 65-89,1969$.

TEIXEIRA NETO, R.O. et al. "Teoria de Congelamento e Descongelamento Estocagem". In: TEIXEIRA NETO, R.O., coord. Curso de Alimentos Congelados, Campinas, ITAL, 1979, p. 41.

WESCHE-EBELING, P. \& MONTGOMERY, M.W. Strawberry polyphenolosidase: its role in antocyanin degradation. Journal of Food Science, Chicago, 55(3):731-733, 1990.

WROLSTAD, R.E.; PUTNAM, T.P. \& VARSEVELD, G.W. Color Quality of Frozen Strawberries: Effect of Anthocyanin, pH, Total Acidity and Ascorbic Acid Variability. Journal of Food Science, Chicago, 35 (4):448-453, 1970 .

WROLSTAD, R.E.; SKREDE, G.; LEA, P. \& ENERSEN, G. Influence of Sugar on Anthocyanin Pigment Stability in Frozen Strawberries. Journal of Food Science, Chicago, 프. (4):1064-1065, 1072,1990 . 